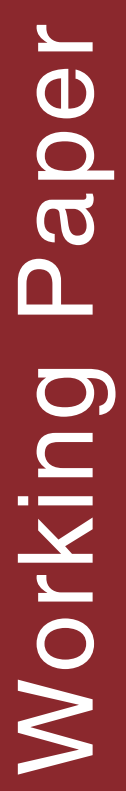

Endri Martini, James M. Roshetko, Pratiknyo Purnomosidhi, Gerhard Sebastien 



\section{Agroforestry extension needs for land rehabilitation in East Sumba, East Nusa Tenggara, Indonesia}

Endri Martini, James M Roshetko, PratiknyoPurnomosidhi, Gerhard Sabastian

Working paper no. 232 


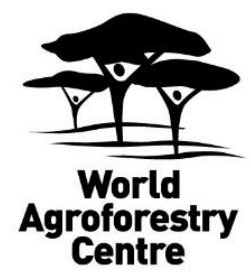

\section{Correct citation:}

Martini E, Roshetko JM, Purnomosidhi P, Sabastian G. 2016. Agroforestry extension needs for land rehabilitation in East Sumba, East Nusa Tenggara, Indonesia. Working Paper no. 232. Bogor, Indonesia: World Agroforestry Centre (ICRAF) Southeast Asia Regional Program. DOI: http://dx.doi.org/10.5716/WP16078.PDF

Titles in the Working Paper series disseminate interim results on agroforestry research and practices to stimulate feedback from the scientific community.Other publication series from the World Agroforestry Centre includeagroforestry perspectives, technical manuals and occasional papers.

Published by the World Agroforestry Centre

ICRAF Southeast Asia Regional Program

JL. CIFOR, Situ Gede, Sindang Barang, Bogor 16680

PO Box 161, Bogor 16001, Indonesia

Tel: +62 2518625415

Fax: +62 2518625416

Email: icraf-indonesia@cgiar.org

ICRAF Southeast Asia website: http://www.worldagroforestry.org/region/southeast-asia/

(C) World Agroforestry Centre 2016

Working Paper 232

\section{Photographs:}

The views expressed in this publication are those of the author(s) and not necessarily those of the World Agroforestry Centre.Articles appearing in this publication may be quoted or reproduced without charge, provided the source is acknowledged. All images remain the sole property of their source and may not be used for any purpose without written permission of the source. 


\section{About the authors}

Endri Martini is currently working at the World Agroforestry Centre (ICRAF) as Agroforestry Extension Specialist since 2011. Previously she worked at ICRAF since 2001 on various issues of agroforestry related to biodiversity conservation and community development. She obtained her Master of Science degree in natural resources and environmental management from University of Hawaii at Manoa, USA. Her bachelor degree was from Institute Pertanian Bogor, Forestry Faculty, majoring in Silviculture.

James M Roshetko is an Agroforestry Systems Scientist with the World Agroforestry Centre (ICRAF). He is the Leader of ICRAF's Southeast Asia Trees and Market Unit with 37 years of experience, including 19 years in Indonesia and 28 years in South and Southeast Asia. Jim is the Senior Team Leader of the IRED-ICRAF project: linking knowledge to action project. His research interests focus on smallholder tree-based systems as viable agricultural and natural resources management systems that contribute significantly to local livelihood objectives and global environmental goals. He has a $\mathrm{PhD}$ in Geosciences and Natural Resource Management from the University of Copenhagen and a MSc in Forest and Agroforestry Management from Michigan State University.

Pratiknyo Purnomosidhi is an Agroforestry Specialist at World Agroforestry Centre (ICRAF) since 1993. He worked at ICRAF on issue related to carbon above - below ground and hydrology in agroforestry systems in Lampung, Jambi, and involve in community development activities on agroforestry management in Nanggroe Aceh Darussalam and Sulawesi. He obtained his Master of Science on Soil and Water Management from Gadjah Mada University, Indonesia and his bachelor degree in Soil Science from Brawijaya University, Indonesia.

Gerhard Sabastian is an Associate Scientist in Agroforestry System with the World Agroforestry Centre (ICRAF). He has worked for ICRAF with 20 years of experiences in eight projects of research and development in Indonesia. Gerhard is the Project Manager of IRED-ICRAF project. His major research is in smallholder agroforestry systems with focus on the development of silvicultural management for timber and NTFP species to enhance local livelihoods and sustainable ecosystem services. Gerhard has a PhD in Forestry Management from the Australian National University and a MSc in Natural Resources Management from the Bogor Agricultural University. 


\section{Abstract}

This study was conducted to provide baseline information on agroforestry extension needs to support the successful of agroforestry project goals for land rehabilitation in East Sumba. Results from this baseline study are expected to facilitate the implementation of those approaches in the next 2-3 years, specifically in Haharu subdistrict (the most degraded landscape in East Sumba), and generally in East Sumba district. Survey was conducted via focus group discussions (FGD) with communities in 3 villages in Haharu subdistrict (Wunga, Rambangaru and Kadahang), and with subdistrict extension agents, to collect information on agroforestry extension needs and barriers in land rehabilitation in Haharu subdistrict. Additionally interview with key stakeholders was also conducted with local government agencies (Dinas Pertanian, Dinas Perkebunan and Dinas Kehutanan) and non government agencies (Wahana Visi Indonesia, Yayasan Tananua and Lutheran World Relief), to receive inputs on barriers for land rehabilitation in Haharu subdistrict and potentials type of agroforestry extension activities that can be linked to their current programs. Results showed that barriers in land rehabilitation mostly related to limited water resources, poor soil fertility, cattle disturbance, fire, limited facilitation to ensure the sustainability of tree planting program, and limited quality seedlings. Based on those identified barriers, agroforestry extension needs are identified and discussed in this paper. Agroforestry farmer field school is a key option of extension approach that is requested by farmers to enhance their knowledge and capacity to manage their garden and for land rehabilitation in Haharu subdistrict. Integrated with the agroforestry farmer field school, demonstration trials on agroforestry are expected to be established in each sub village in the next 2-3 years as an interactive media to learn about agroforestry practices that can help to rehabilitate land in Haharu. Type of agroforestry system that can be developed in the demonstration trials can be assessed from combination of priority species that farmers are interested in. Extension agents and farmers need to work collaboratively and intensively to ensure farmer participation and learning during planning, establishment and management of the demonstration trials.

Keywords: Demonstration trials, Wunga, Rambangaru, Kadahang, Haharu 


\section{Acknowledgements}

This study was supported by the Indonesian Rural Economic Development (IRED) Sumba program, which is implemented Wahana Visi Indonesia (WVI) in collaboration with the World Agroforestry Centre (ICRAF) and Lutheran World Relief (LWR) through funding from the Australian Government Department of Foreign Affairs and Trade (DFAT). We appreciate the assistance and contribution of the collaborating communities, non-governmental organizations and local government offices in East Sumba district, particularly communities and extension agents in Haharu subdistricts, East Sumba district. We are also appreciate the inputs and assistances given by WVI team in East Sumba. 


\section{Contents}

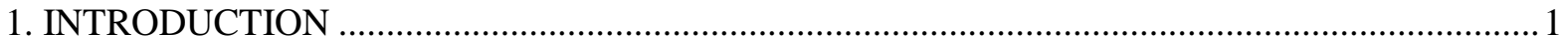

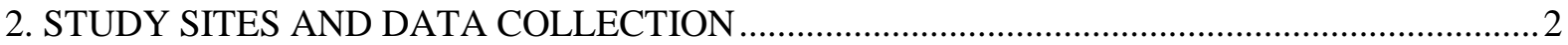

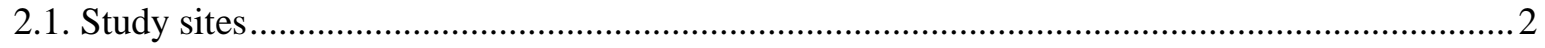

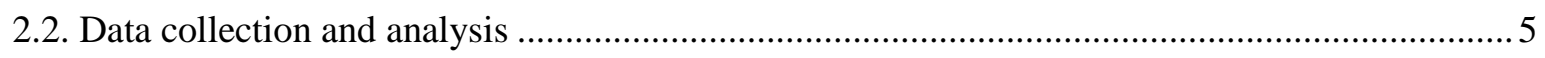

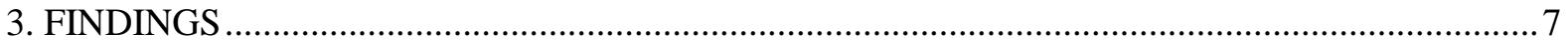

3.1. Existing tree planting and farmer-managed natural regeneration programs in Haharu subdistrict

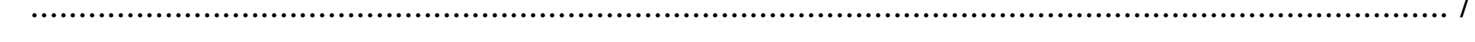

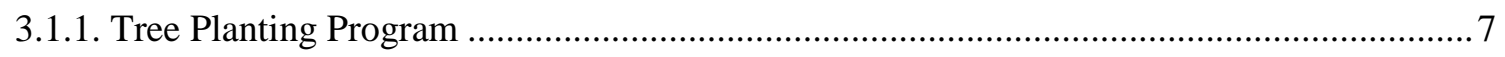

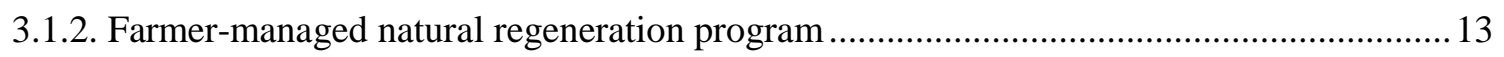

3.2. Extension needs for land rehabilitation in Haharu subdistrict .............................................. 14

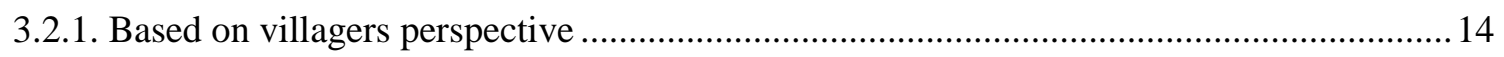

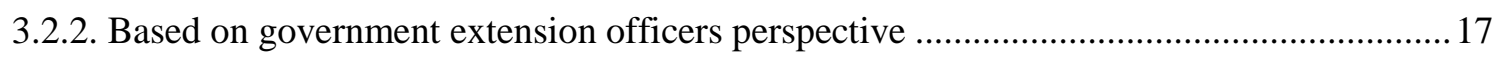

3.3. Potential agroforestry programs for land rehabilitation in Haharu subdistrict .......................... 18

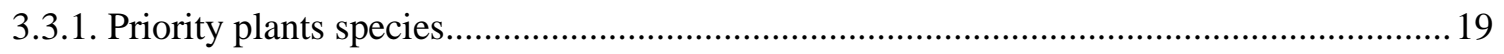

3.3.2. Agroforestry Farmer Field School for land rehabilitation................................................ 20

3.3.3. Agroforestry demonstration plots for land rehabilitation................................................ 21

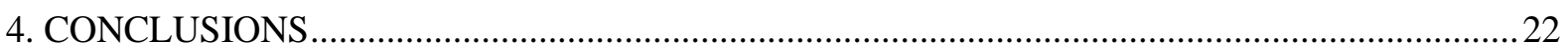

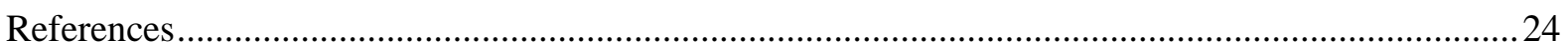

Annex 1. Sketchs of Wunga, Kadahang and Rambangaru villages .............................................2 26 


\section{List of Tables}

Table 1. Characteristics of villages in Haharu subdistrict, East Sumba district..................................... 4

Tabel 2. Government tree planting programs in Haharu subdistrict .................................................. 8

Table 3. Tree planting programs initiated by NGO in 2016 in Haharu subdistrict............................... 9

Table 4. Tree planting programs received by villagers in Wunga, Kadahang and Rambangaru

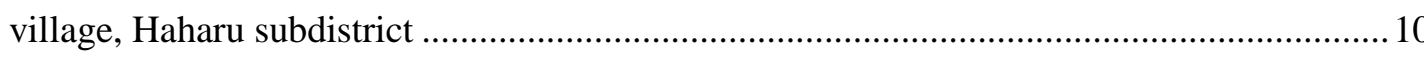

Tabel 5. Trends of barriers in tree planting based on farmers perspective from 10-20 years ago

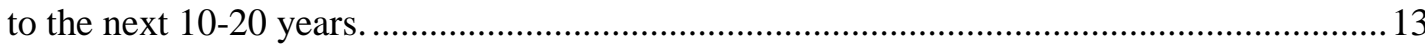

Table 6. Existing extension services from goverment and non government agencies in Haharu

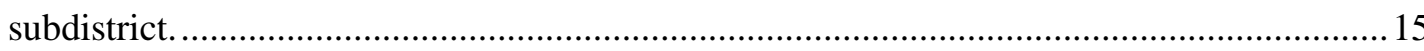

Table 7. Extension services needs based on farmer perspectives in Haharu subdistrict....................... 16

Table 8. Training and extension needs for extension officers in Haharu subdistrict. ........................... 18

Table 9. Tree species that are abundant and grow well in Haharu subdistrict...................................... 19

Table 10. Plant species prioritized to be planted by farmers in Haharu sub district ............................. 20

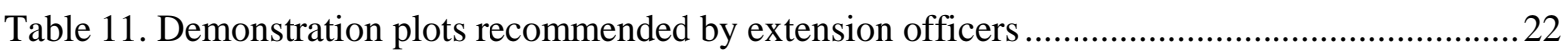

\section{List of Figures}

Figure 1. Map of study location in East Sumba, East Nusa Tenggara.................................................. 3

Figure 2. Annual rainfalls in Haharu subdistrict from year 2008 to year 2014 ..................................... 4

Figure 3. Total agricultural crop production in Haharu subdistrict from year 2009 to 2014 from

Haharu in Figure.

Figure 4. Total number of livestocks in Haharu subdistrict from year 2009 to 2014 from Haharu in Figure.

Figure 5. Average annual rainfall pattern in each village based on discussion with the villagers

in Wunga, Kadahang and Rambangaru, Haharu subdistrict.

Figure 6. Wunga village, Haharu subdistrict, East Sumba …............................................................... 26

Figure 7. Kadahang village, Haharu subdistrict, East Sumba ............................................................26

Figure 8. Rambangaru village, Haharu subdistrict, East Sumba.........................................................2 


\section{List of Plant Species}

\begin{tabular}{llll}
\hline Tree species & Indonesian name & $\begin{array}{l}\text { Local Name } \\
\text { (Sumbanese) }\end{array}$ & Botanical Name \\
\hline Mangrove tree & Bakau & Bakau & Sonneratia spp. \\
\hline Cassia tree & Johar & Johar & Senna siamea \\
\hline Indian ash tree & Kedondong pagar & Kehi & Lannea coromandelica \\
\hline Indonesian bay-leaf & Salam & Lobung & Syzygium polyanthum \\
\hline Lac tree & Kesambi & Kosambi & Scheilechera oleosa \\
\hline Borassus & Lontar & Minggit/Tuak & Borassus flabellifer \\
\hline Coconut & Kelapa & Kelapa & Cocos nucifera \\
\hline Gmelina & Jati putih & Jati putih & Gmelina arborea \\
\hline Teak & Jati & Jati & Tectona grandis \\
\hline Mahagony & Mahoni & Mahoni & Swietenia mahagony \\
\hline Betel nut & Pinang & Pinang & Areca catechu \\
\hline Piper & Sirih & Sirih & Piper betle \\
\hline Cashew & Mente & Mente & Anacardium occidentale \\
\hline Hog plum & Kedondong & Kedondong & Spondias dulcis \\
\hline Sandalwood & Cendana & Cendana & Santalum album \\
\hline Java olive tree & Kepuh & Kelumpang & Sterculia foetida \\
\hline Breadfruit & Sukun & Sukun & Artocarpus altilis \\
\hline Jackfruit & Nangka & Nangka & Artocarpus heterophyllus \\
\hline & & Mnjuwatu & Pleiogynium timoriense \\
\hline & & & \\
\hline
\end{tabular}




\section{INTRODUCTION}

East Nusa Tenggara Timur (ENT) is the southeastern most province of the Indonesia archipelago. ENT, along with the neighboring provinces of West Nusa Tenggara (WNT) and Maluku, experience ecological conditions that is not normally associates with Indonesia. These provinces are composted of small islands, have limited human populations, are isolated from other areas of Indonesia, and endure long annual dry seasons. This is a sharp contrast to the humid tropical conditions prevailing on the country's better known, larger islands of Sumatra, Java, Bali Kalimantan, Sulawesi and Papua (Roshetko and Mulawarman, 2002).

Small islands in southeastern Indonesia face many ecological and environmental problems. They are vulnerable to natural disasters: volcanic eruptions, earthquakes, landslides and cyclones. Coastal areas compose a large percentage of the land. Proximity to the ocean directly affected the climate of the island. Watersheds are small and ground water limited. The natural environment is specialized, containing many unique species. The land area is steep and soil erosion high. Landuse systems are often of indigenous origin and specialized for the unique combination of local ecological and socioeconomic conditions. There is an inherent danger of land degradation due to excess utilization pressure on the limited land resource (Stubenvoll, 2000; Monk et al., 1997).

Sumba is one of the main islands in ENT and contains four districts: West Sumba, East Sumba, Central Sumba, and Southwest Sumba. The landscape of East Sumba district is highly degraded, with around $86 \%$ of the total areas are categorized as degraded, i.e. 191,454 ha of its state forest land and 411,495 ha of non-forestland (Indonesian Ministry of Forestry, 2002). Forests and farms were fired every year. Grassland is the main land cover in the district, maintained through annual burning as a resource for grazing livestock. People in East Sumba are very poor with annual household incomes for year 2013 of Rp 8,236,127 (US\$ 866; AUS\$1,029), with 29\% of total households under poverty line (with monthly income below Rp 260,247) (BPS, 2015). Household food security is not assured. There is interest by communities and the government to rehabilitate the landscape as a means of establishing tree-based farming systems to diversify farming systems, obtain food security, enhance livelihoods, improve soil and water conservation, and provide other ecosystem services. However, the harsh environmental conditions limit the success of land rehabilitation programs in East Sumba.

Generally, there are two approaches in land rehabilitation, i.e. by tree planting and by farmer management of natural regeneration. Tree planting is the common approach conducted by many agencies, while the costs is higher than with natural regeneration, tree establishment and growth can be accelerated. While the natural regeneration has low cost, in most cases it require longer time achieve the same impact. The best approach is to combine those two approaches in land rehabilitation. In the case of East Sumba, both approaches have been implemented, however when each approach is appropriate and how the two can be used synergistically needs to be studied and evaluated. Over the past 30 years, tree planting programs have been implemented by various actors to rehabilitate the degraded areas of East Nusa Tenggara (including East Sumba), however the successful rate have been 
low due to the barriers in the implementation of land rehabilitation programs (Hutabarat, 2006). Agroforestry systems is promoted as one of landuse system that is expected to support the successful of rehabilitation program (Njurumana, 2008; Njurumana and Prasetyo, 2010), such as in the IRED (Indonesia Rural Economic Development) Sumba program.

The IRED Sumba program was initiated in 2015 under the leadership of WahanaVisi Indonesia with funding from the Australian Government Department of Foreign Affairs and Trade (DFAT).The World Agroforestry Centre (ICRAF) and Lutheran World Relief (LWR) assist in program implementation. The IRED project targets to directly benefit 3,000 farmers and indirectly benefit more than 10,000 community members in ENT Province. The program use agroforestry to restore grazing lands across 5,000 hectares and drive increased productivity (IRED project description, 2015). In the IRED project, effectiveness of tree planting for food security, livelihoods and environmental services (ESs) enhancement are promoted through community nursery development and demonstration trials. Agroforestry extension activities and approached are conducted to achieve the project targets.

In East Sumba, farmers have limited accesses to farm management and technology and markets. District agricultural extension agents are also have limited knowledge on tree-based production systems and environmental services (ESs). Thus, this study is conducted to provide baseline information on agroforestry extension needs to support the successful of agroforestry project goals for land rehabilitation in East Sumba. Result from this baseline is expected to help in the implementation of those identified needs in the next 2-3 years, specifically in Haharu subdistrict, and generally in East Sumba district.

\section{STUDY SITES AND DATA COLLECTION}

\subsection{Study sites}

Survey was conducted in Haharu subdistrict that is located in the northern part of East Sumba district, East Nusa Tenggara province (Figure 1). Total area of Haharu subdistrict is 88090 ha consists of 7 villages, with total population in 2015 is 6166 persons $\left(10\right.$ persons $\left./ \mathrm{km}^{2}\right)$ or $2.5 \%$ of total population in East Sumba district. Haharu is known as more critically degraded if compare to the other subdistricts. Based on Schmidt-Ferguson climate type, Haharu is classified as type E or semi arid with savana land cover. 


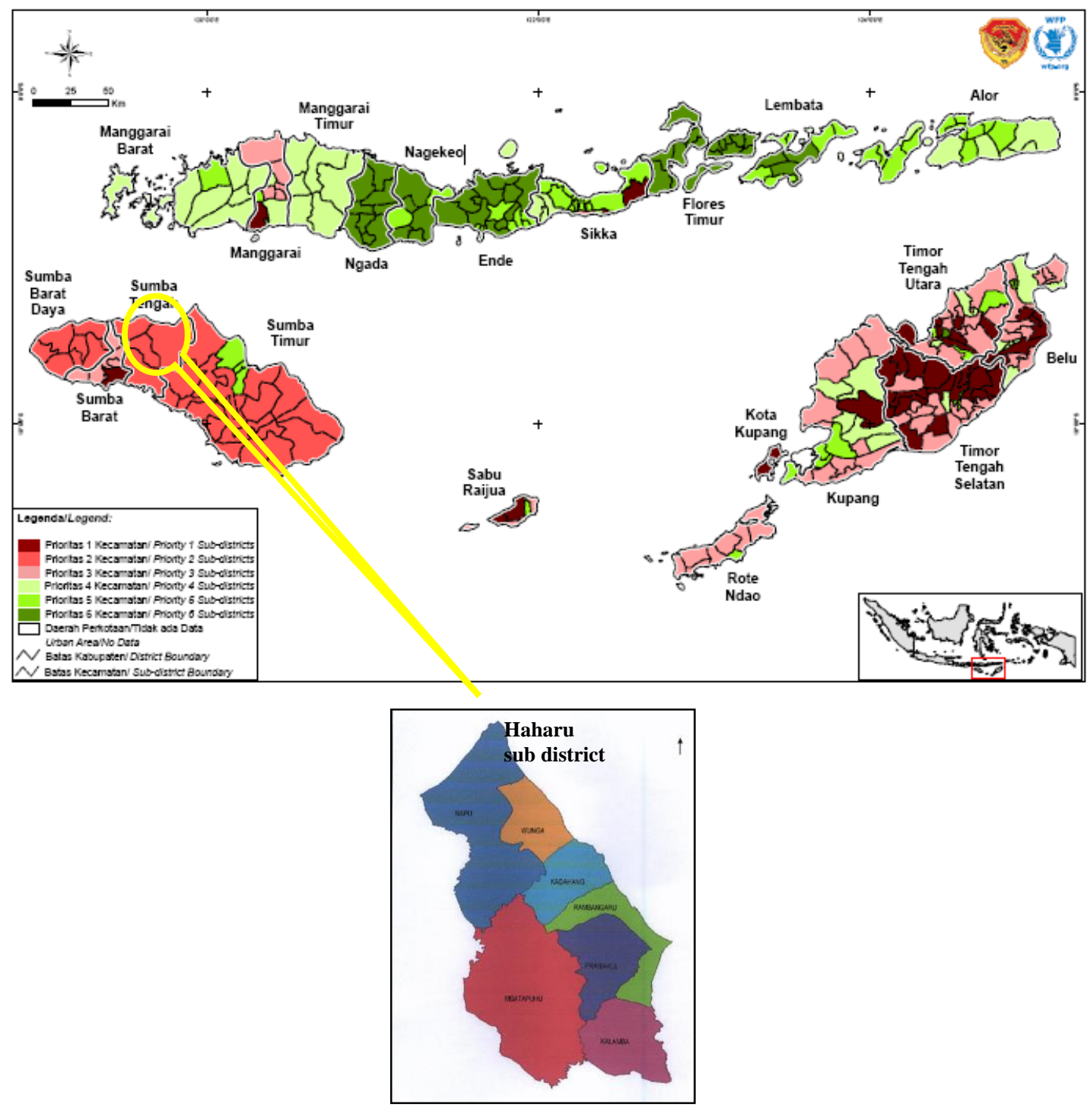

Source: Food security and vulnerability Atlas of Nusa Tenggara Timur (2010) and Haharu in Figures (2014).

Figure 1. Map of study location in East Sumba, East Nusa Tenggara.

Total rainfall in Haharu subdistrict is considered low, i.e. around $1000 \mathrm{~mm}$ per year with only 4 wet months (Dec-Mar) (Figure 2.). The soil characteristics are dominated by limestone, and undulating terrain with altitude from zero to around $320 \mathrm{~m}$ above sea levels. Water is not uniformly available in all villages.Water is scarce particularly in villages that are located near the sea, i.e. Wunga, Kadahang, Praibakul and Kalamba villages. While Rambangaru, Napu, and Mbatapuhu are the villages with relatively have sufficient water. 


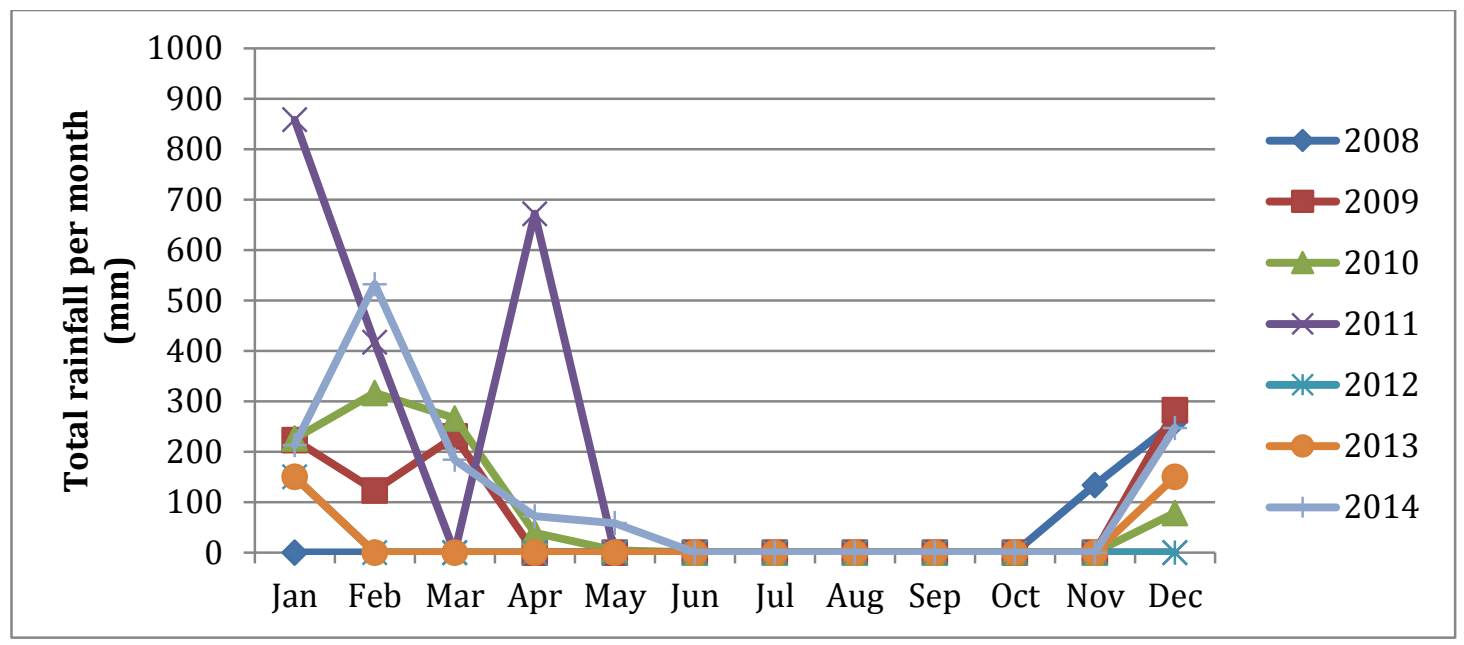

Source: Haharu subdistrict in Figure from year 2008 to 2014.

Figure 2. Annual rainfalls in Haharu subdistrict from year 2008 to year 2014

The main source of livelihood for the people in Haharu district is agriculture (83\%), followed by livestock (9\%) and fishing (8\%), see Table 1. Sumbanese is the dominant ethnicity in the area, with Sumbanese used as the main language followed by Indonesian. The average level of education in Haharu subdistrict is elementary school. Forests in the subdistrict are mainly located in Napu village with 3,375 ha production forest and 14,231 ha protected forest.

Table 1. Characteristics of villages in Haharu subdistrict, East Sumba district.

\begin{tabular}{|c|c|c|c|c|c|c|c|}
\hline \multirow{2}{*}{ Village } & \multirow{2}{*}{$\begin{array}{l}\text { Area } \\
(\mathrm{Ha})\end{array}$} & \multirow{2}{*}{$\begin{array}{l}\text { Altitude } \\
\text { (m asl) }\end{array}$} & \multirow{2}{*}{$\begin{array}{l}\text { Total } \\
\text { springs }\end{array}$} & \multirow{2}{*}{$\begin{array}{l}\text { Total } \\
\text { HH }\end{array}$} & \multicolumn{3}{|c|}{ Percentage of total $\mathrm{HH}(\%)$} \\
\hline & & & & & Farmers & Fishermens & $\begin{array}{l}\text { Cattle } \\
\text { ranchers }\end{array}$ \\
\hline Rambangaru & 6140 & 18 & 4 & 350 & 67.9 & 11.1 & 15.3 \\
\hline PraiBakul & 10500 & 79 & 3 & 216 & 91.7 & 1.6 & 4.0 \\
\hline Mbatapuhu & 21240 & 375 & 4 & 270 & 90.3 & 0.0 & 8.1 \\
\hline Kadahang & 2350 & 234 & 2 & 173 & 75.2 & 13.8 & 9.9 \\
\hline Wunga & 2240 & 207 & 1 & 219 & 85.5 & 2.9 & 9.4 \\
\hline Napu & 14260 & 20 & 4 & 209 & 78.4 & 11.4 & 8.1 \\
\hline Kalamba & 3420 & 227 & 3 & 88 & 89.6 & 0.0 & 9.0 \\
\hline
\end{tabular}

Sources: Haharu subdistrict in Figure, 2014

Based on Haharu subdistrict in Figure 2014 data, peanuts, cassava, sweet potato, maize, rice and mung beans are the short term food crops that contributes to local people livelihood in Haharu (Figure 3.). Total production of food crops from 2009 to 2014 is still considered low due to the low total areas planted, although its productivity is considered to be at the same rate or even higher than the average productivity at district level, particularly for peanuts, cassava and sweet potatoes. Total area for food 
crops in Haharu subdistrict is lower than other district in East Sumba subdistrict. Free range chicken, goats, pigs, cows, horses and buffalos are all common livestock that contribute to local livelihood, with free range chicken composing the greatest livestock population in Haharu subdistrict (Figure 4.).

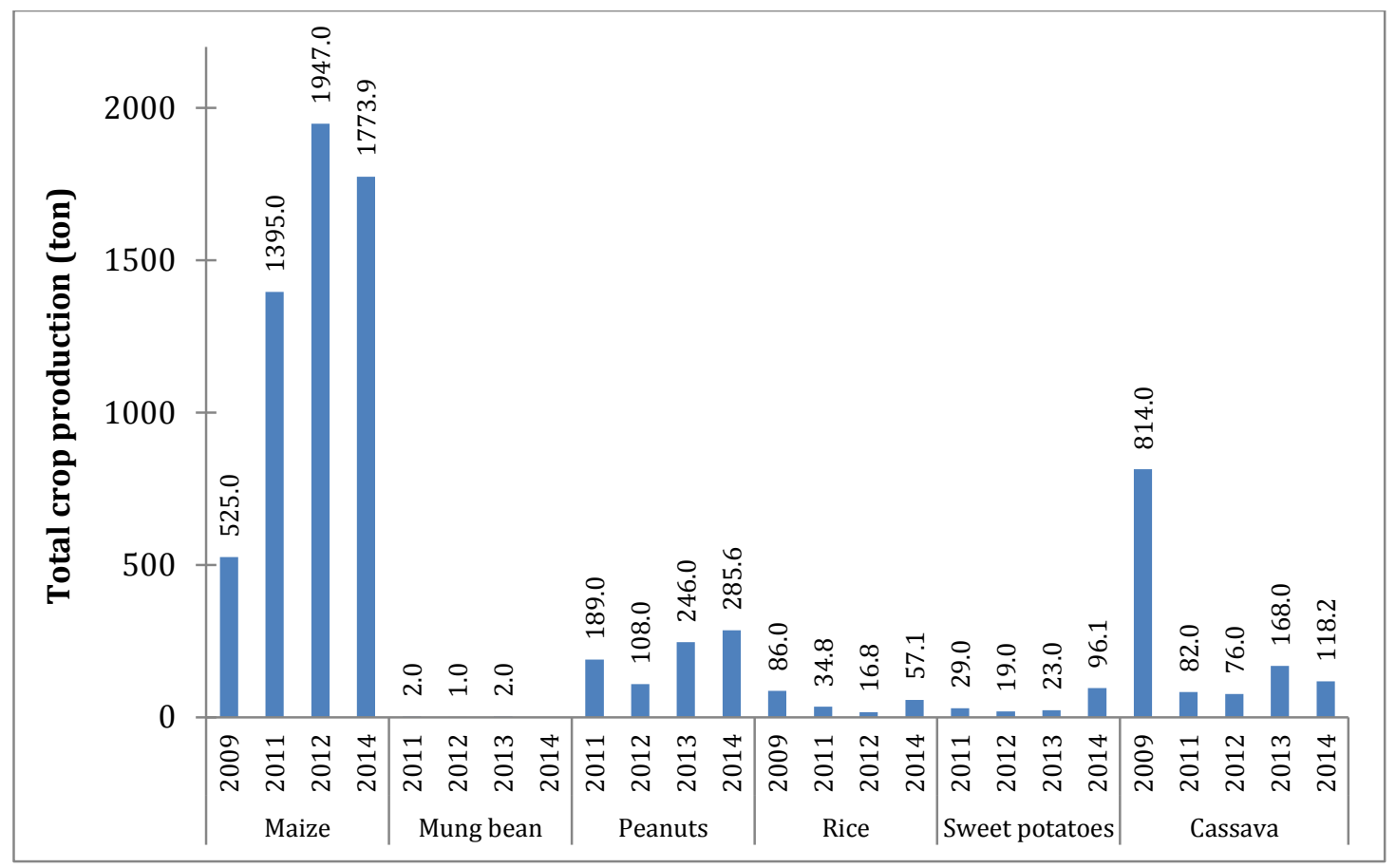

Figure 3. Total agricultural crop production in Haharu subdistrict from year 2009 to 2014 from Haharu in Figure.

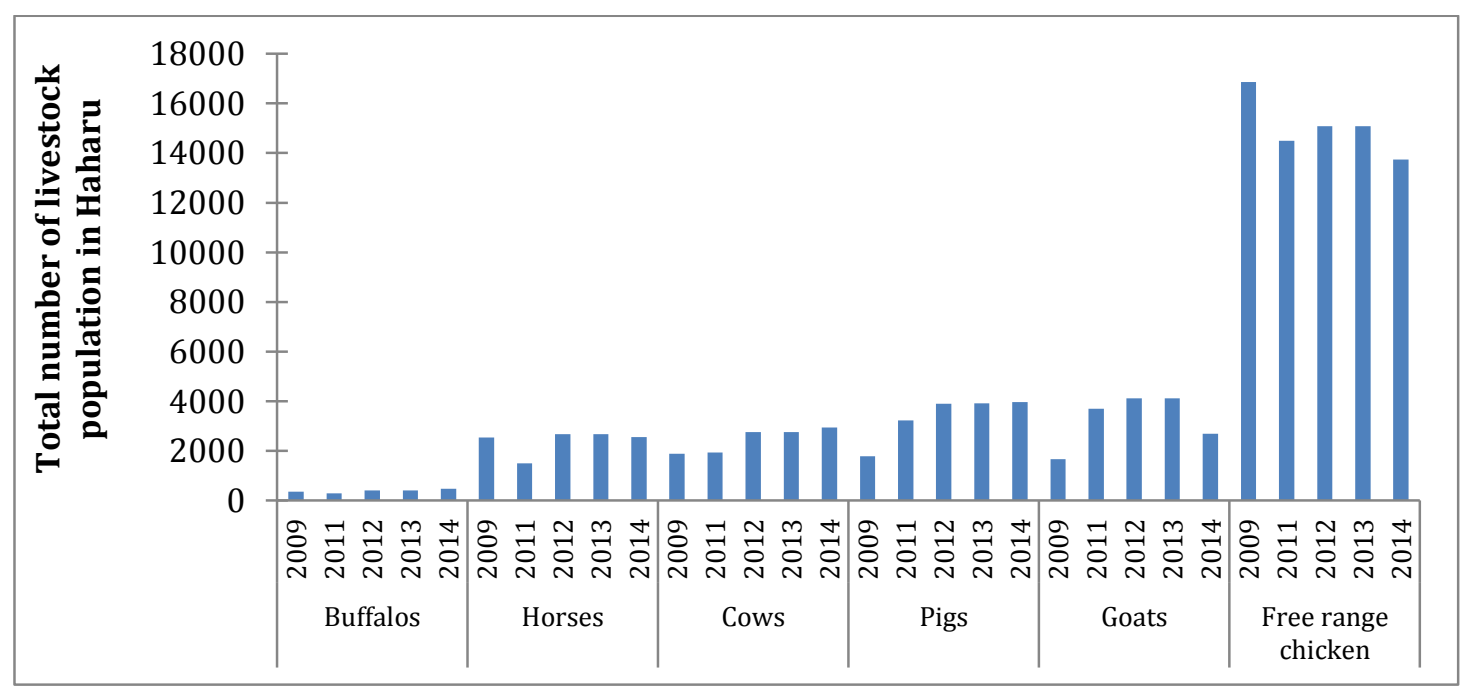

Figure 4. Total number of livestocks in Haharu subdistrict from year 2009 to 2014 from Haharu in Figure.

\subsection{Data collection and analysis}

The survey was conducted from 6 to14 April 2016, focusing on Haharu subdistrict where the IRED project operates. Information on previous and expected agricultural extension activities related to tree 
planting program at subdistrict level were collected, as well as information on tree planting programs and its barriers in East Sumba district. The information was analyzed qualitatively and quantitatively via descriptive statistics.

The information was collected through:

(i) Focus Group Discussions with 3 FGD communities at village level and 1 FGD with government extension agents at subdistrict level. FGDs at the community level were conducted by involving 8-12 participants (mixed female and male) in 3 of the 7 IRED project villages. Village selection was based on the different level of community access to water (Figure 5), which influences the successful of tree planting program, i.e.:

- Wunga village, classified as having limited access to water resources, i.e. only 1 spring.

- Kadahang village, classified as having intermediate access to water resources, i.e. having 2 springs

- Rambangaru village, classified as having good access to water resources, i.e. having 4 springs

FGD with extension agent at subdistrict level was conducted by inviting all extension agents who are working in Haharu subdistrict (10 persons).

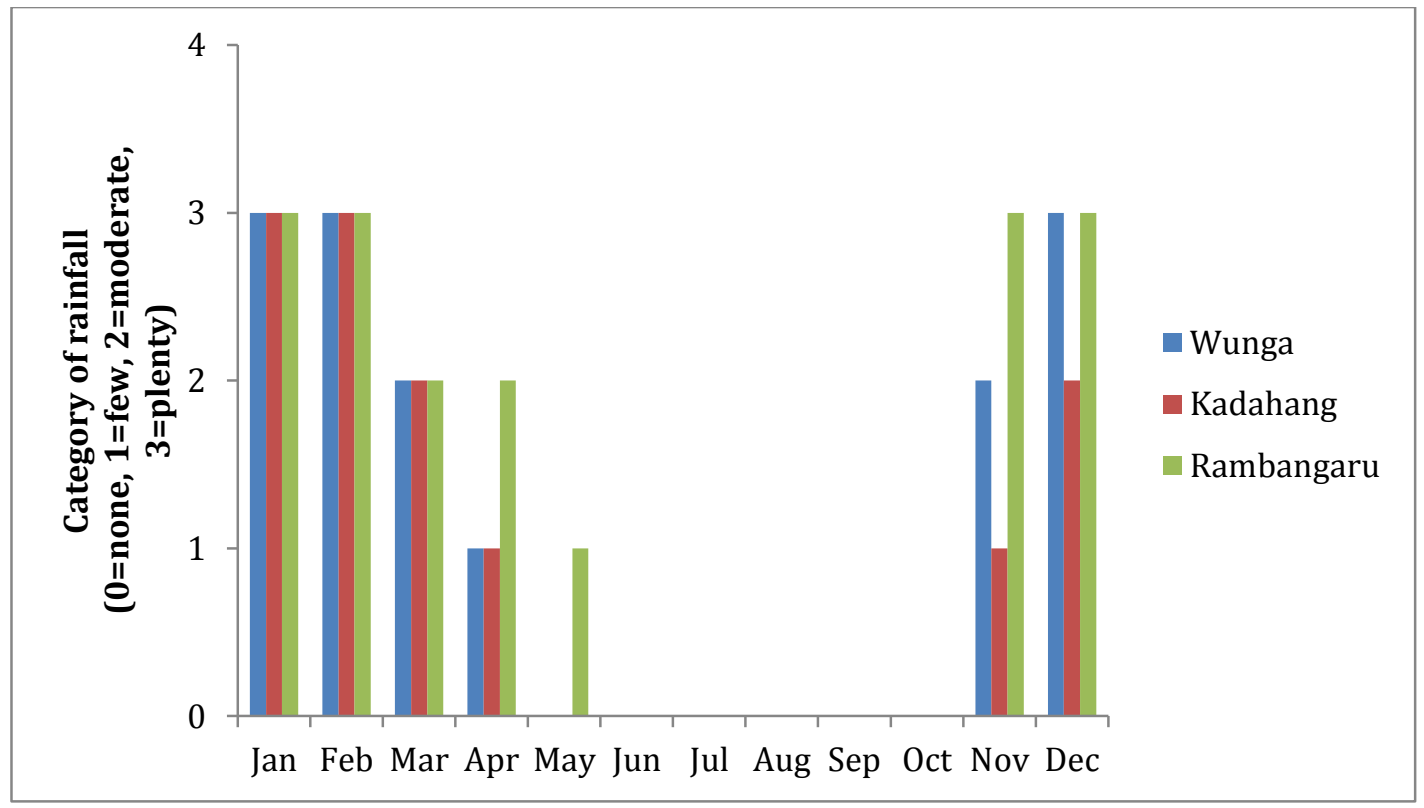

Figure 5. Average annual rainfall pattern in each village based on discussion with the villagers in Wunga, Kadahang and Rambangaru, Haharu subdistrict.

(ii) Interview with key stakeholders via snowball method was conducted with the objective to understand the tree planting and Farmer Managed Natural Regeneration (FMNR) challenges and opportunities in East Sumba. Those key stakeholders were: 
- Agricultural Department of East Sumba district (collect information related to Dinas program that link to Tree Planting (fruit trees)).

- Forestry and Estate Crops Department of East Sumba district (collect information related to Forestry Department program that link to Tree Planting).

- District Extension Agency, East Sumba district (collect information on number of extension officers, the programs, capacity building needs related to Tree Planting).

- Wahana Visi Indonesia (WVI), Lutheran World Relief (LWR), and Yayasan Tananua (collect information on Tree Planting and FMNR implementation, progress, challenges, and potential activities that related with capacity building).

(iii) Statistics information on demographics, agricultural production, and forest resources in East Sumba district was obtained from the district statistic office (Badan Pusat Statistik, BPS).

(iv) Secondary data on species prioritization in the Haharu subdistrict was obtained from survey conducted by ICRAF in January 2016. While for agricultural extension needs at household level was obtained from household survey conducted by WVI team in 2016.

\section{FINDINGS}

\subsection{Existing tree planting and farmer-managed natural regeneration programs in Haharu subdistrict}

\subsubsection{Tree Planting Program}

\subsubsection{Government tree planting programs}

In Haharu subdistrict there are 4 government agencies (from district level) that are involved in the implementation of tree planting programs, i.e. agricultural, forestry, estate crop and the extension agencies. Each agency has its specific roles and programs on tree planting (Table 2.). Based on discussion with key stakeholders in each agency, barriers to implement their tree planting programs varied by agency, the key barriers are limited water availability, cattle; fire; limited availability of good quality seedlings; land tenure; and limited facilitation to ensure the sustainability of tree planting program.

Agricultural agency at district lemvel is developing home garden agriculture as part of land rehabilitation program because this landuse system is considered more appropriate in areas with limited water resources and cattle grazing problems. If compares to the other departments, agricultural department recognizes limited seedling quality as one of the barriers to a successful tree planting 
program. Currently quality fruit species seedlings are often imported from other island such as from Soe (in Timor Island) for citrus. The main challenges for developing centre of quality seedlings in East Sumba is the limited water resource, limited sources for quality mother trees, and less prioritization from the local government.

The forest agency's tree planting programs promote the establishment of individual forests (hutan rakyat) on private land. The objective of the hutan rakyat program is regreening or afforestation of private land. The forestry department supplied seeds, polybags, water pipeline, and small size water reservoir. Farmers need to organize group to be eligible to participate in the program. Sandalwood, eucalyptus, paraserianthes are the main species promoted through this program. Hutan rakyat program is also has objective to protect springs and wells.

Tree planting programs of the estate crop agency focused to the southern part of East Sumba district (i.e. Pinupaharu, Tabundung, Ponggaludu sub districts) that have more appropriate biophysical conditions for development of cashew, coconut, beetle nut (pinang), and piper (sirih). Cashew is considered to have high economic value compared to the other species, thus every year there are programs for cashew plantation expansion and post-harvest handling training in collaboration with Industrial and Trade Department at district level.

Tabel 2. Government tree planting programs in Haharu subdistrict

\begin{tabular}{|c|c|c|c|}
\hline $\begin{array}{l}\text { Government } \\
\text { agency }\end{array}$ & $\begin{array}{l}\text { Role in tree planting } \\
\text { programs }\end{array}$ & $\begin{array}{l}\text { Existing tree planting programs in } \\
2016\end{array}$ & $\begin{array}{l}\text { Barriers in tree } \\
\text { planting programs }\end{array}$ \\
\hline $\begin{array}{l}\text { Agricultural } \\
\text { agency at } \\
\text { district level }\end{array}$ & $\begin{array}{l}\text { Developing and } \\
\text { delivering fruit tree } \\
\text { planting for food } \\
\text { security issues }\end{array}$ & $\begin{array}{l}\text { Home garden program for intercropping } \\
\text { peanuts and maize under mango, citrus } \\
\text { and rambutan trees. }\end{array}$ & $\begin{array}{l}\text { 1. Limited water } \\
\text { availability } \\
\text { 2. Cattles disturbance } \\
\text { 3. Limited quality } \\
\text { seedlings from good } \\
\text { quality mother trees for } \\
\text { fruits species }\end{array}$ \\
\hline $\begin{array}{l}\text { Forestry } \\
\text { agency at } \\
\text { district level }\end{array}$ & $\begin{array}{l}\text { Developing and } \\
\text { delivering tree } \\
\text { planting for land } \\
\text { rehabilitation and } \\
\text { conservation } \\
\text { programs }\end{array}$ & $\begin{array}{l}\text { a. In State Forest area: Sandalwood } \\
\text { Plantation with the objective to increase } \\
\text { sandalwood population in the state forest; } \\
\text { b. Outside State Forest area: } \\
\text { Sandalwood Plantation with Hutan } \\
\text { Rakyat scheme; Village Tree Nursery } \\
\text { (Kebun Bibit Desa/KBD and Kebun Bibit } \\
\text { Rakyat/KBR) of sandalwood, mahagony, } \\
\text { gmelina, and injuwatu. }\end{array}$ & $\begin{array}{l}\text { 1. Cattles disturbance } \\
\text { 2. Fire } \\
\text { 3.Limited water } \\
\text { availability } \\
\text { 4. Social issues (land } \\
\text { tenure issues) }\end{array}$ \\
\hline $\begin{array}{l}\text { Estate Crop } \\
\text { agency at } \\
\text { district level }\end{array}$ & $\begin{array}{l}\text { Developing and } \\
\text { delivering tree-based } \\
\text { industrial crops } \\
\text { planting programs }\end{array}$ & $\begin{array}{l}\text { a. Enhancement of cashew production. } \\
\text { b. Enhancement of coconut production } \\
\text { (to be implemented in 2017) }\end{array}$ & $\begin{array}{l}\text { 1. Limited facilitation to } \\
\text { ensure the sustainability } \\
\text { of tree planting program. }\end{array}$ \\
\hline $\begin{array}{l}\text { Extension } \\
\text { agency at } \\
\text { district and } \\
\text { subdistrict } \\
\text { level }\end{array}$ & $\begin{array}{l}\text { Facilitating tree } \\
\text { planting programs } \\
\text { deliver by Agricultural } \\
\text { department, Forestry } \\
\text { department, and } \\
\text { Estate Crop } \\
\text { department }\end{array}$ & $\begin{array}{l}\text { a. Agriculture: food security program from } \\
\text { national program and home garden } \\
\text { development from district program; } \\
\text { b. Forestry: KBR from national program } \\
\text { and KBD from district program. } \\
\text { c. Estate crop: Enhancement of cashew } \\
\text { and coconut production from district } \\
\text { program and from provincial programs. }\end{array}$ & $\begin{array}{l}\text { 1. Cattles distrubance } \\
\text { 2. Limited water } \\
\text { availability }\end{array}$ \\
\hline
\end{tabular}

Source: Interview with key stakeholders in each government agency. 
Extension agency performs the key role of ensuring the sustainability of tree planting activities through intensive facilitation and monitoring. There are a number of challenges faced by the extension agency, such as limited number of extension agents and limited technical capacity of those extension agents. The agency acknowledges further training is required.

\subsubsection{Tree planting programs initiated and implemented by Non Governmental Organization} (NGOs)

In East Sumba, there are numbers of NGO working in community development on food security, poverty alleviation and environmental issues. Yayasan Tananua is the longest established. Yayasan Tananua partners with numerous other organizations in East Sumba and other areas, i.e.Pelita, Koppesda, World Neighbours, Kemitraan Indonesia, Yakersum, Yasalti, FALP (Forum Anda Lindu Pala on marketing issues), YSS (Yayasan Sumba Sejahtera), WVI (Wahana Visi Indonesia), Bumi Lestari, Stimulant, Pahadang Majoru and Local Government Agencies. Collaboration with government agencies is conducted by Yayasan Tananua particularly to obtain seedlings for tree planting programs. Other important NGOs that currently work in Haharu district are Wahana Visi Indonesia (WVI) with 10 years experience in the area, and Lutheran World Relief (LWR).

Table 3. Tree planting programs initiated by NGO in 2016 in Haharu subdistrict

\begin{tabular}{|c|c|c|c|}
\hline NGO & $\begin{array}{l}\text { Role in tree } \\
\text { planting programs }\end{array}$ & $\begin{array}{l}\text { Existing tree planting programs in } \\
2016\end{array}$ & $\begin{array}{l}\text { Barriers in tree } \\
\text { planting programs }\end{array}$ \\
\hline \multirow[t]{3}{*}{$\begin{array}{l}\text { Yayasan } \\
\text { Tananua }\end{array}$} & \multirow{3}{*}{$\begin{array}{l}\text { Community } \\
\text { development, and } \\
\text { conduct training for } \\
\text { farmer groups. }\end{array}$} & $\begin{array}{l}\text { a) In collaboration with LWR on climate } \\
\text { smart agriculture in Wunga village } \\
\text { (Haharu). }\end{array}$ & \multirow{3}{*}{$\begin{array}{l}\text { 1. Limited water } \\
\text { availability } \\
\text { 2. Cattles } \\
\text { disturbances }\end{array}$} \\
\hline & & $\begin{array}{l}\text { b) In collaboration with The Nature } \\
\text { Conservancy (TNC) Indonesia for } \\
\text { community development in Napu village } \\
\text { on Community Forestry program. }\end{array}$ & \\
\hline & & $\begin{array}{l}\text { c. In collaboration with Pelita and } \\
\text { Koppesda on SPARC (Strategic Planning } \\
\text { and Action to Strengthen Climate } \\
\text { Resilience of Rural Communities) with } \\
\text { objective to strengthen community } \\
\text { resilience on food security, water } \\
\text { resource and livelihood security in a } \\
\text { changing climate. }\end{array}$ & \\
\hline \multirow[t]{2}{*}{$\begin{array}{l}\text { Wahana Visi } \\
\text { Indonesia (WVI) }\end{array}$} & \multirow{2}{*}{$\begin{array}{l}\text { Community } \\
\text { development, and } \\
\text { conduct training for } \\
\text { farmer groups. }\end{array}$} & \multirow{2}{*}{$\begin{array}{l}\text { Indonesia Rural Economic Development } \\
\text { (IRED) with the objective to help farmers } \\
\text { regenerate degraded farmlands and } \\
\text { forests, increase yields, improve quality, } \\
\text { enhance market access and boost } \\
\text { income. }\end{array}$} & $\begin{array}{l}\text { 1. Cattles } \\
\text { disturbances }\end{array}$ \\
\hline & & & 2. Fire \\
\hline \multirow[t]{2}{*}{$\begin{array}{l}\text { Lutheran World } \\
\text { Relief (LWR) }\end{array}$} & \multirow{2}{*}{$\begin{array}{l}\text { Provide aids for } \\
\text { building water } \\
\text { reservoir and }\end{array}$} & $\begin{array}{l}\text { a) Indonesia Rural Economic } \\
\text { Development (IRED) }\end{array}$ & \multirow[t]{2}{*}{$\begin{array}{l}\text { 1. Limited water } \\
\text { availability }\end{array}$} \\
\hline & & b) Climate Smart Agriculture & \\
\hline
\end{tabular}

Source: Interview with key stakeholders at each NGO. 


\subsubsection{Tree planting programs received by farmers and its barriers}

At village level, many tree planting programs have been implemented in the past 10 years, however the tree survival rates were low. Based on the discussion with the farmers, seedling survival varied from $0 \%$ up to $50 \%$ (Table 4.). However there is no systematic document on the seedlings survival rates. The numbers given by the farmers were estimation based on their perceptions.

Table 4. Tree planting programs received by villagers in Wunga, Kadahang and Rambangaru village, Haharu subdistrict

\begin{tabular}{|c|c|c|c|c|c|}
\hline Village & Agency & Tree planting programs & Year & $\begin{array}{l}\text { Tree } \\
\text { survival }\end{array}$ & Note \\
\hline \multirow{5}{*}{ Wunga } & $\begin{array}{l}\text { CRS- } \\
\text { AUSAID }\end{array}$ & $\begin{array}{l}\text { Social delegation program to } \\
\text { distribute candlenut, mango, } \\
\text { and breadfruit seedlings. }\end{array}$ & 2003 & $50 \%$ & $\begin{array}{l}\text { Some of the } \\
\text { surviving candlenut } \\
\text { trees are fruiting. }\end{array}$ \\
\hline & $\begin{array}{l}\text { Provincial } \\
\text { Forestry } \\
\text { Agency }\end{array}$ & $\begin{array}{l}\text { Seedlings distribution } \\
(1 \mathrm{HH}=5-10 \text { seedlings }) .\end{array}$ & 2006 & $50 \%$ & $\begin{array}{l}\text { The trees have } \\
\text { grown well }\end{array}$ \\
\hline & Pidra & $\begin{array}{l}\text { Seedlings distribution of } \\
\text { mahagony and gmelina, } \\
\text { through farmer group. }\end{array}$ & 2007 & $50 \%$ & \\
\hline & WVI & $\begin{array}{l}\text { Demonstration plots and } \\
\text { FMNR, planting sandalwood, } \\
\text { breadfruit, mango. }\end{array}$ & 2010 & $50 \%$ & \\
\hline & $\begin{array}{l}\text { District } \\
\text { Estate Crop } \\
\text { Agency }\end{array}$ & Coconut and Cotton plantation & $\begin{array}{l}2008 \\
2010\end{array}$ & $0 \%$ & $\begin{array}{l}\text { Coconut and cotton } \\
\text { were not priorities in } \\
\text { Wunga. No } \\
\text { facilitation. }\end{array}$ \\
\hline \multirow{6}{*}{ Kadahang } & $\begin{array}{l}\text { Village } \\
\text { Developmen } \\
\text { t Fund }\end{array}$ & $\begin{array}{l}\text { Land rehabilitation with } \\
\text { mahagony and gmelina }\end{array}$ & 2007 & $25 \%$ & \\
\hline & \multirow{2}{*}{$\begin{array}{l}\text { District } \\
\text { Forestry } \\
\text { Agency }\end{array}$} & $\begin{array}{l}\text { KBD (Kebun Bibit Desa) } \\
\text { program with mahagony and } \\
\text { gmelina species, } 50000 \\
\text { seedlngs were given to } \\
\text { farmers. }\end{array}$ & 2014 & $30 \%$ & $\begin{array}{l}\text { Seedlings were } \\
\text { distributed and } \\
\text { planted. }\end{array}$ \\
\hline & & $\begin{array}{l}\text { Distribution of } 11000 \text { seedlings } \\
\text { for springs conservation and } \\
\text { protection. }\end{array}$ & 2014 & $4 \%$ & $\begin{array}{l}\text { There are around } \\
400 \text { trees survived. }\end{array}$ \\
\hline & $\begin{array}{l}\text { Yayasan } \\
\text { Sumba } \\
\text { Sejahtera } \\
\text { (YSS) }\end{array}$ & $\begin{array}{l}\text { Seedlings distribution of } \\
\text { sandalwood, mahogany and } \\
\text { gmelina. }\end{array}$ & $\begin{array}{l}2011- \\
2014\end{array}$ & $25 \%$ & $\begin{array}{l}\text { Sandalwood trees } \\
\text { are still occurred on } \\
\text { a } 1 \text { ha area. }\end{array}$ \\
\hline & WVI & $\begin{array}{l}\text { Demonstration plot and } \\
\text { seedlings distribution. }\end{array}$ & $\begin{array}{l}2008- \\
2016\end{array}$ & $25 \%$ & \\
\hline & $\begin{array}{l}\text { Pelita } \\
\text { Sumba }\end{array}$ & $\begin{array}{l}\text { Seedlings distribution of } \\
\text { mahagony. }\end{array}$ & 2016 & N.A. & $\begin{array}{l}\text { The program was } \\
\text { started in early } \\
2016 \text {. }\end{array}$ \\
\hline \multirow[b]{2}{*}{ Rambangaru } & WVI & $\begin{array}{l}\text { Seedling distribution, of } \\
\text { mahagony, gmelina and teak. }\end{array}$ & 2013 & $40 \%$ & \\
\hline & $\begin{array}{l}\text { District } \\
\text { Forestry } \\
\text { Agency }\end{array}$ & $\begin{array}{l}\text { KBR that distributed } 50,000 \\
\text { seedlings, with mahagony, } \\
\text { gmelina and breadfruit. }\end{array}$ & 2014 & $45 \%$ & \\
\hline
\end{tabular}

Source: FGD with villagers in each village 
From field observation and discussion with the villagers, the locations of the successful trees plantings were near springs, rivers, beaches and in flat fertile land. Tree species which survived near rivers and on flat fertile land were those with economic value (coconut and other estate crops), while those that survived near springs are species with less economic value but have high potential to protect the springs.

Low numbers of survival rate of the planted trees were basically due to some barriers occured during and after tree planting programs. Based on discussion with villagers, fire is the most common barrier particularly in Kadahang and Rambangaru, cattle disturbances is the second most important barrier, limited water resources as the third, plant pests and diseases as the fourth and soil fertility as the fifth. In Rambangaru limited availability of quality seedlings is also an important tree planting barrier. In Kadahang, human resource is a key barrier, specifically the limited knowledge on livestock management and fire control. There is opportunity to implement trainings to improve farmers'knowledge on livestock management and fire controls.

Fires occur mainly during the dry season. The main cause of fire is human carelessness when burning trash and disgarding cigerettes; another cause is the local habit of burning dry grasslands to stimulate a flush of new grass growth for cattle feed. Currently there are no village regulations that govern the way to burn the field for rejuvenating the grassess. However, in the last few years has been quite a lot of education and socialization of fire controls, and it is quite effective in reducing the number of field fire incidences.

Cattle disturbance usually occurs because cattle are set free to graze and owners do not control were the cattle go, main gardens are not fenced, and there are no village regulations regarding landuse for grazing and gardens. In Haharu subdistrict, Kalamba village has started developing village regulations to recognize separate areas for grazing and gardens. This cattle disturbance happens in all villages in Haharu subdistrict.

Limited water resource is also the main factor causes the low survival rate of the planted trees. In some locations such as in Wunga, water shortages have always occurred, but in other areas such as in Kadahang and Rambangaru, limited water resource has become an issue only in the past 10 years. Farmers feel drought is more frequent in Haharu nowadays due to deforestation from illegal logging and the frequent annual burning of grasslands.

Between the villages in Haharu subdistrict, sources of water varied, between rain water, springs, rivers and wells. Currently in Wunga, the community receives aids from goverment and other organizations such as LWR and Tananua to build small size water reservoir with size varies from $2 \times 2$ meter to $4 \mathrm{x}$ 4 meter.

Dry season in Haharu usually occurs during the months of May to October. In dry season, households typically use springs, wells, or obtaning water from other villages. They may even buy water. As for gardening, in Rambangaru and Kadahang, which are located near the river, farmers plant their crops along the riverbanks. While in Wunga, farmers stop agricultural activities in dry season. During the dry 
season cattles are usually drinking in other villages or in the river. Sometimes, many cattles die in the dry season due to a shortage of water and food.

In the past 5 years, the incidence of pests and diseases in crops and livestock were increasing. According to farmers, it happens because of the drought that has caused crop and livestock stressed and thus susceptible to pests and diseases. However, some farmers like those in Kadahang do not know the cause of the increase in pests and diseases problems. Currently the species most commonly attacked by pests are gmelina, coconuts, mangroves (Sonneratia spp.) and kosambi (Scheilechera oleosa). The trunk and leaves of kosambi are attacked by white insect mostly happens in May; this pest has only occurs in the past 5 years. While the common diseases in livestock are swine fever, bloating goats, lame cows, and flu in chickens.

Soils types in Haharu varied between villages depending on location. Villages near the coast tend to have limestone based soils, which applies to Wunga, Napu, part of Kadahang, and part of Rambangaru. Inland villages, such as Kalamba and Mbatapuhu, tend to have deeper, darker, more fertile soil. Farmers do not know how to improve fertility of thinner limestone soils, thus agricultural activities in those areas are prone to failure during drier years.

Based on their experience and learning during the last 10-20 years, most farmers feel the subsequent 10-20 years will be better in regards to food security, control of fire and tree cover (Table 5.). However, they feel problems with water resource and cattle grazing issues will not be better in the next 10-20 years, particularly if there is no assistance to explore ways of addressing those problems. Thus, any assistances or extension services on water resources and cattle management becomes important to increase the success of tree planting programs in Haharu. 
Tabel 5. Trends of barriers in tree planting based on farmers perspective from 10-20 years ago to the next 10-20 years.

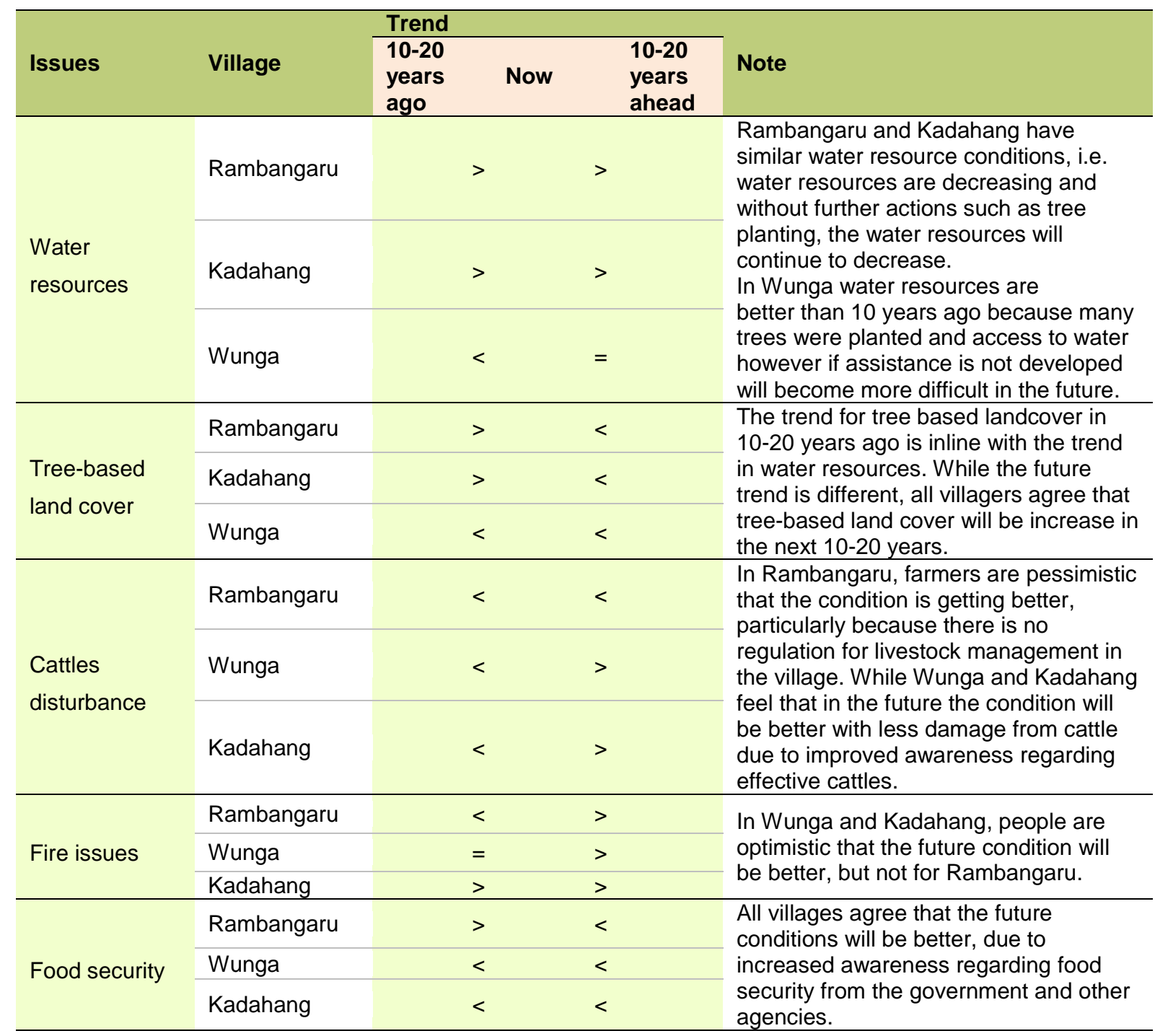

Source: FGD at village level

According to farmers, they have not yet received direct economic benefits from tree planting, because the trees are still young. However, they expect to benefit in the next 20-30 years from past tree planting activities, through: (i) increased family income; (ii) exsistence of on-farm timber resources for their own use; and (iii) sale of timber. Besides economical benefit, they also expect to gain environmental benefits such as cooler air temperaturse, comfortable atmosphere, and decreasing problems of drought.

\subsubsection{Farmer-managed natural regeneration program}

Farmer-managed natural regeneration (FMNR) is a land-restoration technique that increasing food and timber production, and involves the systematic regeneration and management of trees and shrubs from tree stumps, roots and seeds (Rinaudo, 2012). In Haharu subdistrict, WVI introduced the FMNR via the INFOCUS (Increase Food Security within the Community through Sustainable Livelihood and Natural 
Resource Management System) project with main objective to motivate farmers to plant and maintain trees in their landscape. Cattle grazing and fire are the barriers to successful FMNR implementation in Haharu. FMNR is also known as "palotang" in Sumbanese.

Under palotang program farmers are trained to to develop healthy trees through pruning and thinning. Farmers were required to prune trees monthly, with every HH required to maintain 600 trees. Farmers located their palotang sites in areas with less fire and cattle issues. The maintained trees were marked with string and monitored every month.

Currently farmers have few palotang sites that were pruned and thinned, and they are still monitoring tree growth of the previous palotang sites. Based on discussion with the farmers, the growth of the trees are good, however most of the prunned trees are trees with low economic value, thus they have not yet received direct monetary benefit from the palotang program. They have received knowledge benefits regarding tree maintenance. In the future, the farmers will implement the knowledge they received through palotang in their own garden.

\subsection{Extension needs for land rehabilitation in Haharu subdistrict}

\subsubsection{Based on villagers perspective}

Based on discussion with the villagers, many extension activities are conducted by numerous organizations in the subdistrict covering forestry, agricultural, fisheries and livestock management (Table 6.). Training on agroforestry has been conducted by WVI in all villages. The presence of government extension services was only identified in Kadahang and Rambangaru, while extension by private extension agents occurred in all villages. This shows the important of the role of private extension agents in Haharu subdistrict.

Based on study conducted at household level by WVI in 2016, general topics on agroforestry become the third most requested by the farmers in Haharu subdistrict, with agriculture as the first and livestock management on the second. Farmers participation in agricultural extension still limited due to no information given to farmers, no invitation for farmers and location of the training is far from their home. Type of extension media that farmers received the most were leaflet, booklet and movie, respectively. 
Table 6. Existing extension services from goverment and non government agencies in Haharu subdistrict.

\begin{tabular}{|c|c|c|c|c|c|}
\hline Villages & $\begin{array}{l}\text { Extension } \\
\text { institutions }\end{array}$ & Extension topics & $\begin{array}{l}\text { Annualvisit } \\
\text { Frequency }\end{array}$ & $\begin{array}{l}\text { Extension } \\
\text { method }\end{array}$ & $\begin{array}{l}\text { Extension } \\
\text { media }\end{array}$ \\
\hline \multicolumn{6}{|c|}{ Government extension agents (BP3K) } \\
\hline Kadahang & $\begin{array}{l}\text { Livestock } \\
\text { extension } \\
\text { officer }\end{array}$ & $\begin{array}{l}\text { Livestock management } \\
\text { (goats, cow and pig) }\end{array}$ & 1 & Discussion & None \\
\hline $\begin{array}{l}\text { Rambangaru, } \\
\text { Kadahang }\end{array}$ & $\begin{array}{l}\text { Forestry } \\
\text { extension } \\
\text { officer }\end{array}$ & $\begin{array}{l}\text { Meeting with forestry } \\
\text { farmer groups; Forestry } \\
\text { regulation }\end{array}$ & Occasionally & Discussion & $\begin{array}{l}\text { Film } \\
\text { shows }\end{array}$ \\
\hline $\begin{array}{l}\text { Rambangaru, } \\
\text { Kadahang }\end{array}$ & $\begin{array}{l}\text { Fisheries } \\
\text { extension } \\
\text { officer }\end{array}$ & $\begin{array}{l}\text { Marine and coastal } \\
\text { conservation; } \\
\text { Enviromentally friendly } \\
\text { fish catching; Coral reefs } \\
\text { conservation; Mangrove } \\
\text { planting. }\end{array}$ & 1 & $\begin{array}{l}\text { Discussion } \\
\text { (Socialization) }\end{array}$ & Leaflet \\
\hline Rambangaru & $\begin{array}{l}\text { Agricultural } \\
\text { extension } \\
\text { officers }\end{array}$ & $\begin{array}{l}\text { Pests and diseases } \\
\text { handling in maize and } \\
\text { peanuts. }\end{array}$ & 1 & Discussion & Leaflet. \\
\hline \multicolumn{6}{|c|}{ Private extension agents (NGOs) } \\
\hline Rambangaru & Bethesda & Tree planting. & 4 & Discussion & None \\
\hline Rambangaru & Curches & Land rehabilitation. & 4 & $\begin{array}{l}\text { Discussion } \\
\text { (Socialization) }\end{array}$ & None \\
\hline Rambangaru & ICRAF-IRED & Tree nursery. & 24 & $\begin{array}{l}\text { Training and } \\
\text { discussion }\end{array}$ & Booklet \\
\hline Wunga & Tananua & $\begin{array}{l}\text { Nursery; Production and } \\
\text { application of organic } \\
\text { fertilizers. }\end{array}$ & 12 & Training & Booklet \\
\hline Wunga & $\begin{array}{l}\text { LWR and } \\
\text { Tananua }\end{array}$ & $\begin{array}{l}\text { Developing rainfall water } \\
\text { reservoir. }\end{array}$ & 12 & Discussion & None \\
\hline Kadahang & Pelita Sumba & $\begin{array}{l}\text { Tree planting; Soil and } \\
\text { water conservation. }\end{array}$ & 48 & $\begin{array}{l}\text { Discussion } \\
\text { and training }\end{array}$ & Poster \\
\hline $\begin{array}{l}\text { Rambangaru, } \\
\text { Wunga, } \\
\text { Kadahang }\end{array}$ & WVI & $\begin{array}{l}\text { Tree planting; FMNR; } \\
\text { Demonstration trials; } \\
\text { Agroforestry. }\end{array}$ & 12 & $\begin{array}{l}\text { Discussion } \\
\text { and training }\end{array}$ & Booklet \\
\hline
\end{tabular}

Source: FGD with villagers

Most of the farmers think that extension services have some limitation particularly on conveying new technologies that are needed by the farmers. Based on the discussion with farmers, we identified the needs through 2 different approaches (Table 7.). First by asking directly the topics they want to learn, and the second by evaluating their needs based on review of their dry season livelihood strategies. Farmers' dry-season livelihood strategies are of the utmost importance as that is when drought, food insecurity and limited income generation opportunities occur. 
Table 7. Extension services needs based on farmer perspectives in Haharu subdistrict

\begin{tabular}{|c|c|c|}
\hline Subjects & Villages & Topics \\
\hline \multirow{3}{*}{$\begin{array}{l}\text { Dryland } \\
\text { agriculture }\end{array}$} & \multirow{3}{*}{ Wunga } & Land preparation \\
\hline & & Use of superior seedlings for dryland restoration \\
\hline & & Pest and diseases management for dryland systems \\
\hline \multirow{5}{*}{ Fisheries } & Rambangaru & Regulations and socialization on fishing technologies \\
\hline & \multirow{2}{*}{ Kadahang } & Tools and technology to improve fish production \\
\hline & & Fish marketing (selling fish, bargaining skills, access to price information) \\
\hline & \multirow{2}{*}{ All villages } & Post harvest processing and marketing of fish \\
\hline & & Fishing technologies and skills. \\
\hline \multirow{13}{*}{ Agroforestry } & \multirow{4}{*}{ Wunga } & Agroforestry products marketing \\
\hline & & Tree planting preparation \\
\hline & & Tree spacing and planting \\
\hline & & Cultivation of cashew, mango, breadfruit and candlenut \\
\hline & $\begin{array}{l}\text { Wunga, } \\
\text { Rambangaru }\end{array}$ & $\begin{array}{l}\text { Pests and diseases handling, particularly for coconut and other estate } \\
\text { crops }\end{array}$ \\
\hline & \multirow{2}{*}{ Rambangaru } & Tree management \\
\hline & & Identification of mother trees for producing quality seed \\
\hline & \multirow{3}{*}{ Kadahang } & Fallow management \\
\hline & & Drip irrigation \\
\hline & & Vegetative propagation \\
\hline & \multirow{3}{*}{ All villages } & $\begin{array}{l}\text { Identification tree species with high economic value and match biophysical } \\
\text { conditions in Haharu. }\end{array}$ \\
\hline & & $\begin{array}{l}\text { Nursery management (including fertilizing, germinating seeds, and } \\
\text { preparing seedlings to be planted in the field). }\end{array}$ \\
\hline & & $\begin{array}{l}\text { Socialization of forest use regulation to stop illegal logging and field } \\
\text { burning. }\end{array}$ \\
\hline \multirow{5}{*}{ Agriculture } & Wunga & $\begin{array}{l}\text { Facilitating linkages between farmer groups and local government, } \\
\text { particularly to foster farmer group involvement in government programs }\end{array}$ \\
\hline & \multirow{2}{*}{ Kadahang } & Drip irrigation \\
\hline & & Use and management of chemical and organic fertilizers \\
\hline & \multirow{2}{*}{$\begin{array}{l}\text { Kadahang, } \\
\text { Rambangaru }\end{array}$} & Maize seeds production, pests and diseases handling \\
\hline & & Dry season irrigation of vegetable and maize crops \\
\hline \multirow{4}{*}{$\begin{array}{l}\text { Livestock } \\
\text { management }\end{array}$} & \multirow{2}{*}{ Kadahang } & Livestock management of fowl and cattles \\
\hline & & Livestock marketing \\
\hline & $\begin{array}{l}\text { Kadahang, } \\
\text { Wunga, } \\
\text { Rambangaru }\end{array}$ & $\begin{array}{l}\text { Livestock pests and diseases management (this particularly due to the } \\
\text { increase incidences of bloating goats, swine fever, lame cow, flu in chicken. }\end{array}$ \\
\hline & $\begin{array}{l}\text { Kadahang, } \\
\text { Rambangaru }\end{array}$ & Livestock nutrition; Livestock sanitation \\
\hline
\end{tabular}

Source: FGD with villagers 


\subsubsection{Based on government extension officers perspective}

In Haharu subdistrict extension office (BP3K Haharu), there are 10 extension officers, i.e. 1 forestry extension officer, 1 fisheries extension officer, 1 estate crops extension officer, 3 agriculture extension officers and 3 livestock extension officers. The average length of duty in Haharu for extension officer is 5 years, varrying one to 15 years. The highest education level of the extension officers are Bachelor degree (S1).

Discussion with farmers is the most common extension method used by BP3K extension officers in Haharu; other method such as field visit, demonstration plots, or training seldom used due to budget limitations. Other obstacle faced by extension officers is their own limited training, experience and lack of access to capacity building opportunities. Most common extension media distributed by extension officers to farmers is leaflet. Sometimes they also distribute poster produced by other government agencies.

Major role of extension officers in tree planting program is as facilitator of programs that are initiated by other agencies such as from Forestry Department at district level, and the Estate Crop Department. Extension officers have responsibility to monitor and assist the implementation of those tree planting programs from the other government agencies. Based on the extension officer's experience, the programs that have high success story are programs that are requested by farmers and involving species that have high economic values, such as cashew and coconut plantation program from Estate Crops Department.

Based on the discussion with extension officers, in facilitating the tree planting programs in Haharu subdistrict, most barriers are biophysical such as soil conditions, climate and water resource, topography and fire. Social barriers were also encountered, particularly those related with grazing management and fire control. Of those barriers, soil conditions are considered the easier and faster to solve by using organic fertilizer and soil supplements (biomass transfer) for improving fertility. Grazing and fire can also be addressed by developing and applying village and district level regulations. Barriers that related with climate and water resource are the one that more difficult and need longer time to be solve. Thus, the short-term extension needs for farmers is to support how to enhance farmers' knowledge in manipulating soil fertility by applying organic fertilizers and for communities is the development and application of appropriate grazing and fire managemtn regulations.

Extension officers feel that their knowledge and capacity need to be enhanced in order to provide better extension services to communities. Lists of training and extension needs for extension officers in Haharu subdistrict as identified in this survey are provided in Table 8 . Tree nursery and production of organic fertilizer are the topics directly related to agroforestry for land restoration. 
Table 8. Training and extension needs for extension officers in Haharu subdistrict.

\begin{tabular}{|c|c|}
\hline Subjects & Topics for training or extension \\
\hline \multirow{4}{*}{ Forestry } & a) Forest tree nursery \\
\hline & b) Concept and application of agroforestry \\
\hline & $\begin{array}{l}\text { c) Individual forest (Hutanrakyat), particularly on its implementation due to the weak } \\
\text { coordination between Forestry Department with Extension Agent at district and subdistrict } \\
\text { level. }\end{array}$ \\
\hline & d) Socialization on new forestry regulation related to conditions in Haharu subdistrict. \\
\hline \multirow{7}{*}{$\begin{array}{l}\text { Livestock } \\
\text { management }\end{array}$} & a) Cattle reproduction \\
\hline & b) Livestock pests and diseases handling \\
\hline & c) Livestock nutrition \\
\hline & d) Post-harvest handling \\
\hline & e) Artificial insemination \\
\hline & f) Livestock vaccination \\
\hline & g) Producing organic fertilizer from cattle dungs \\
\hline \multirow{3}{*}{ Agriculture } & a) Pests and diseases management for food crops and vegetables \\
\hline & b) Demonstration plots for organic agriculture \\
\hline & c) Estimation on agricultural productivity \\
\hline \multirow{3}{*}{ Estate crops } & a) Estate crops nursery \\
\hline & b) Agroforestry and its potential economic benefits \\
\hline & c) Post harvest handling of cashew \\
\hline \multirow{3}{*}{ Fisheries } & a) Aquaculture nursery \\
\hline & b) Pests and diseases management in aquaculture \\
\hline & c) New technologies on aquaculture \\
\hline
\end{tabular}

Source: FGD with extension officers in BP3K Haharu subdistrict.

\subsection{Potential agroforestry programs for land rehabilitation in Haharu subdistrict}

On average the level of education of most farmers in Sumba is elementary school. Thesurvey found that the most appropriate extension approach for those farmers is introducing more practicals technologies via establishing demonstration trials and also via field visit to successful farmers. Those two approaches can be implemented via agroforestry farmer field school, as have been implemented by Martini et al. (2016) in South and Southeast Sulawesi where general farmers are from elementary school and below. For the case of East Sumba, the main topic for the agroforestry farmer field school should be focused on land rehabilitation - tree planting and enhanced management of agroforestry systems.

The first step in planning an agroforestry farmer field school, is to identify the priority species in each village - both the tree species and short term crop species that can be intercropped under agroforestry systems. Farmers' capacity and knowledge on tree and system management need to be enhanced via agroforestry farmer field school. After farmers' capacity is enhanced, the next step is to establish agroforestry demonstration trials. Demonstration trials need to be established via participatory and voluntary approach which is including farmers from designing the plot up to maintaining the plot. 


\subsubsection{Priority plants species}

In a land rehabilitation program, priority plants species can be selected by observing type of plants that are abundant and grow well in the landscape, and plants that are prioritized by farmers. Selecting plants prioritized by farmers will enhance farmers' participation and motivation in managing those species. Farmers are more willing to invest their efforts and time if they have been involved in the selection process and see the potential benefits of those species for improving their livelihood and increasing their income.

Based on the discussion with farmers, many of the tree species currently abundant in Haharu subdistrict have low economic value, such as mangrove species (Sonneratia spp.), johar, kehi, lobung (see Table 9). Yet, farmers recognize that many of the tree species with low economic values have high environmental value.

Table 9. Tree species that are abundant and grow well in Haharu subdistrict

\begin{tabular}{|c|c|c|c|c|}
\hline No. & Tree species & $\begin{array}{l}\text { Newly } \\
\text { introduced }\end{array}$ & $\begin{array}{l}\text { Economic } \\
\text { value }\end{array}$ & Uses \\
\hline 1 & $\begin{array}{l}\text { Bakau/Mangrove tree } \\
\text { (Sonneratia sp.) }\end{array}$ & No & LOW & Coastal conservation \\
\hline 2 & Johar (Senna siamea) & No & LOW & House construction \\
\hline 3 & $\begin{array}{l}\text { Kehi/KayuCina (Lannea } \\
\text { coromandelica) }\end{array}$ & No & LOW & $\begin{array}{l}\text { Living fence, fuelwood, house } \\
\text { construction }\end{array}$ \\
\hline 4 & $\begin{array}{l}\text { Lobung/Salam } \\
\text { (Syzygium polyanthum) }\end{array}$ & No & LOW & $\begin{array}{l}\text { Springs conservation, house } \\
\text { construction, condiment, and medicine. }\end{array}$ \\
\hline 5 & $\begin{array}{l}\text { Injuwatu (Pleiogynium } \\
\text { timoriense) }\end{array}$ & No & Medium & Timber for house construction \\
\hline 6 & $\begin{array}{l}\text { Kosambi (Scheilechera } \\
\text { oleosa) }\end{array}$ & No & Medium & $\begin{array}{l}\text { Fuelwood, fruits for food, shellac (sells } \\
\text { with the price USD1.5 to USD5/kg) }\end{array}$ \\
\hline 7 & $\begin{array}{l}\text { Minggit/Tuak (Borassus } \\
\text { flabellifer) }\end{array}$ & No & Medium & $\begin{array}{l}\text { Handicraft, the flower sap for traditional } \\
\text { alcoholic beverage, the fruits for fodder. }\end{array}$ \\
\hline 8 & $\begin{array}{l}\text { Coconut (Cocos } \\
\text { nucifera) }\end{array}$ & No & Medium & $\begin{array}{l}\text { The fruits for homeuse and market sale } \\
\text { as nuts and copra; timber for house } \\
\text { construction, leaves for roof, fibre for } \\
\text { ropes, coconut oil, broom. }\end{array}$ \\
\hline 9 & $\begin{array}{l}\text { Jati putih (Gmelina } \\
\text { arborea) }\end{array}$ & Yes & High & $\begin{array}{l}\text { House construction; and the leaves are } \\
\text { fodder. }\end{array}$ \\
\hline 10 & Teak (Tectona grandis) & Yes & High & Timber for house construction \\
\hline 11 & $\begin{array}{l}\text { Mahagony (Swietenia } \\
\text { mahagony) }\end{array}$ & Yes & High & Timber for house construction \\
\hline
\end{tabular}

Source: FGD with farmers in Haharu sub district

Injuwatu and kosambi are two interesting species that occur naturally in the landscape and grow well under the harsh climatic conditions in Haharu subdistrict. Both species have economic values; however, the growth of those species is quite slow and required time to reach size of economic value. While 
minggit and coconuts have faster growth compared to kosambi and injuwatu, the economic value of their products are low. Thus, currently farmers are more interested to new introduced species that can grow fast and well under Haharu conditions and have better economic value, such as timber trees, cashew, and breadfruit. Timber trees are for long term income, while cashew, betel nut and breadfruit are expected to provide annual income starting 5-10 years after establishment (Table 10). While for monthly income farmers are expected to gain benefits from planting short term plants such as mung beans, peanuts, shallot, garlic, tomato, and maize.

Table 10. Plant species prioritized to be planted by farmers in Haharu sub district

\begin{tabular}{|c|c|c|c|c|c|}
\hline \multirow{2}{*}{ Village } & \multicolumn{5}{|l|}{ Priority } \\
\hline & 1 & 2 & 3 & 4 & 5 \\
\hline \multicolumn{6}{|c|}{ Short termincome plant class } \\
\hline Kadahang & Mung beans & Peanuts & Arab beans & Water melon & Tomato \\
\hline Kalamba & Peanuts & Arab beans & Shallot & Cassava & Eggplant \\
\hline Mbatapuhu & Shallot & Eggplant & Bitter melon & Arab beans & Mung beans \\
\hline Napu & Tomato & Chili & Eggplant & Peanuts & Mung beans \\
\hline Praibakul & Garlic & Shallot & Brassica & Tomato & Maize \\
\hline Rambangaru & Maize & Peanuts & Mung beans & Tomato & Chili \\
\hline Wunga & Maize & Peanuts & Bitter melon & Rice & Eggplant \\
\hline \multicolumn{6}{|c|}{ Annual income plant class } \\
\hline Kadahang & Breadfruit & Jackfruit & Neem & Mango & Citrus \\
\hline Kalamba & Betel nut & Cashew & Coffee & Breadfruit & Coconut \\
\hline Mbatapuhu & Breadfruit & Cashew & Mango & Citrus & Coconut \\
\hline Napu & Breadfruit & Jackfruit & Cassia & Hog plum & Mango \\
\hline Praibakul & Breadfruit & Banana & Citrus & Coconut & Cashew \\
\hline Rambangaru & Breadfruit & Papaya & Banana & Citrus & Cassia \\
\hline Wunga & Breadfruit & Citrus & Hog plum & Banana & Mango \\
\hline \multicolumn{6}{|c|}{ Long term income plant class } \\
\hline Kadahang & Teak & Gmelina & Sandalwood & Mahagony & Injuwatu \\
\hline Kalamba & Sandalwood & Teak & Mahagony & Injuwatu & N.A. \\
\hline Mbatapuhu & Mahagony & Teak & Sandalwood & Injuwatu & Paraserianthes \\
\hline Napu & Teak & Sterculia foetida & Mahagony & Marujawa & Injuwatu \\
\hline Praibakul & Sandalwood & Mahagony & Teak & Injuwatu & Gmelina \\
\hline Rambangaru & Teak & Injuwatu & Sandalwood & Mahagony & N.A. \\
\hline Wunga & Sandalwood & Teak & Mahagony & Eucalyptus & Injuwatu \\
\hline
\end{tabular}

Source: Secondary data from FGD with farmers in 7 villages in Haharu subdistrict

\subsubsection{Agroforestry Farmer Field School for land rehabilitation}

Based on the household survey to farmers in Haharu subdistrict, $90 \%$ of the surveyed farmers selected farmer field school as one of the training method applied in Haharu. The survey showed that most of the respondents preferred extension methods that contained practical sessions and face-to-face 
discussions. The concept of farmer field schools, which uses participatory training techniques to achieve learning objectives, fits well with farmers' needs for innovative extension approaches. Agroforestry farmer field schools can be an effective extension approach to enhance farmers' capacity in managing their gardens for higher and sustainable productivity (Martini et al., 2016).

Based on the experience with agroforestry farmer field school (AFFS) implementation in South and Southeast Sulawesi Martini et al. (2016) showed that $97 \%$ of the respondents gained benefit from attending AFFS. New and reliable knowledge or information was perceived as the most important aspect motivating farmers to attend AFFS. After one year of AFFS implementation, $14 \%$ of respondents had generated cash benefits from testing new knowledge learned from AFFS. The amount of money generated depended on the type of knowledge tested. Fertilizing and pruning were important techniques that yielded cash benefits for farmers in the short term (within one year). The evaluation concluded that following AFFS activities implementation, a minimum of one year of facilitation would be required to assist participants to effectively test and adapt the new knowledge learned.

For Haharu case, the focus of the AFFS topics can be identified based on the agroforestry extension needs identified at farmers and extension agents level. As explained in the above sections, topics on tree management of species priority can be combined with other important topics that related with technologies to improve agroforestry role to support livestock management, fire control, and increase the number of trees in the landscape.

\subsubsection{Agroforestry demonstration plots for land rehabilitation}

Agroforestry is a landuse option that can provide multiple economic and environmental benefits to farmers (de Foresta et al., 2000). In small size garden plots, agroforestry can provide benefits from a diverse range of tree and annual species. By combining timber species that provide annual income with annual crop species that provide a short term income, agroforestry systems are expected to improve the livelihood of the owner of the plot. If agroforestry systems are scaled up from the plot to landscape level, it will provide more environmental benefits for the landscape, such as better soil fertility and better microclimate which are essential to support the land rehabilitation programs.

Normally, each farmer develops their own agroforestry systems based on their knowledge, experience and motivation. Radandima (2001) indicated that knowledge and experience of farmers have become the basis for development of Agroforestry program in Sumba. Although, the knowledge and experience of each individual farmer is still limited. Farmers' knowledge could be enhanced particularly on agroforestry concept, crop intercropping and management, selection of priority species, soil fertility management, and propagation of quality seedlings. The establishment of demonstration plot in each sub village would be an appropriate channel to enhance farmers' knowledge via agroforestry extension programs, and this has been applied in ICRAF project sites in Sulawesi, Indonesia (Martini et al., 2014). 
In the agroforestry demonstration plots need to be designed according to the existing plot conditions. In the case of Hararu, East Sumba two general conditions and respective approaches are summarized here.

1) If the land is degraded with tree canopies less than $25 \%$, fast growing, sun tolerant tree species that have economic value should be planted, such as coconuts, jackfruit and candlenut. Kehi (Lannea coromandelica) can also be planted as living fence for providing shade and barrier to cattle; additionally kehi is resistant to fire. Annual crops such as mung beans, maize, and peanuts can also be planted in between trees to provide short term income for the farmer.

2) If the tree canopies have reached $25 \%$ to $50 \%$, shade tolerant crops should be planted, such as pepper, cocoa, coffee and nutmeg can be planted under the existing trees.

Discussion with extension officers in BP3K Haharu resulted in recommendations for developing demonstration trials (Table 11.). These areas are mostly have $25 \%$ of tree canopies, thus option two from above can be applied. Planning, assessment of plot conditions, and implementation must be conducted with farmers, who are the ultimate users and adopters of the technologies being tested. Farmer participation during planning, establishment and management is a must to maximize commitment, learning and innovation.

Table 11. Demonstration plots recommended by extension officers

\begin{tabular}{lll}
\hline Priority & Location & Demplot topics \\
\hline 1 & Kalamba & Intercropping turi-gliricidia-leucaena-mahagony-candlenut \\
\hline 2 & $\begin{array}{l}\text { Rambangaru (Dusun } \\
\text { Hambuang) }\end{array}$ & $\begin{array}{l}\text { Intercropping coconuts-paddy rice field; } \\
\text { Aquaculture in agroforestry systems }\end{array}$ \\
\hline 3 & Intercropping leucaena-coconut-other trees species; \\
& Spaibakul & Spacing - species trials; \\
& Development of cashew agroforestry systems \\
\hline 4 & Kadahang (RT Ndara) & Intercropping leucaena-coconut-gmelina; \\
\hline 5 & Agroforestry techniques to prevent fire \\
\hline 6 & Wapu (Dusun Prailangina) & Intercropping mahagony-gmelina-cashew-leucaena \\
\hline 7 & Barat) & Enrichmnet of existing demonstration plots (established by \\
\end{tabular}

Source: FGD with Haharu subdistrict extension officers

\section{CONCLUSIONS}

Results showed that barriers in land rehabilitation are primarily related to limited water resources, poor soil fertility, cattle disturbance, fire, limited facilitation to ensure the sustainability of tree planting program, and limited quality seedlings. Based on those barriers, immediate extension needs for land rehabilitation in Haharu subdistrict are (i) to enhance farmers' knowledge regarding soil fertility improvement through the use of organic fertilizers and (ii) the development and application of 
appropriate grazing and fire management regulations. Training and capacity building activities for enhancing extension agents' knowledge on tree nursery development and organic fertilizer production will enable extension agents to assist farmers to rehabilitate land through agroforestry.

Agroforestry farmer field school is a key options of extension approach that is requested by farmers to enhance their knowledge and capacity to manage their garden and for land rehabilitation in Haharu subdistrict. In the agroforestry farmer field school, topics on tree management of species priority can be combined with other important topics that related with technologies that can improve agroforestry roles to support good livestock managements, controls fire, and increase the number of trees in the landscape.

Integrated with the agroforestry farmer field school, demonstration trials on agroforestry are expected to be established in each sub village as an interactive media between farmers, extension agents and researchers to learn about agroforestry practices that can help to rehabilitate land in Haharu subdistrict. Extension agents and farmers need to work collaboratively and intensively to ensure farmer participation and learning during planning, establishment and management of the demonstration trials.

Type of agroforestry system that can be developed in the demonstration trials can be assessed from combination of priority species that farmers are interested in. Currently farmers are more interested with new introduced species that grow fast under Haharu conditions and provide a good economic return, such as timber trees, cashew, and breadfruit. Timber trees are cultivated as long term income, while cashew, betel nut and breadfruit are cultivated to provide annual income starting 5-10 years after establishment. For short-term (weekly to monthly) income farmers plant short rotation crops such as mung beans, peanuts, shallot, garlic, tomato, and maize.

In summary, the following are recommended:

1. Enhance farmers' knowledge regarding soil fertility improvement through the use of organic fertilizers;

2. Development and application of appropriate grazing and fire management regulations;

3. Provide training and other capacity building activities for extension agents regard tree nursery development and organic fertilizer production

4. Continue assiting farmers with the introduction, testing and adoption of tree and annual crop species that provide economic benefits;

5. Use the agroforestry field school approach to enhance farmers' awareness, knowledge and experience; and

6. Develop demonstration trials - that are planned, established and managed with farmers with the assistance of government extension agents- as an integrated part of the agroforestry field school approach. 


\section{References}

Badan Pusat Statistik (BPS). 2009. Haharu sub district in Figures year 2009. BPS Kecamatan Haharu.

Badan Pusat Statistik (BPS). 2010. Haharu sub district in Figures year 2010. BPS Kecamatan Haharu.

Badan Pusat Statistik (BPS). 2011. Haharu sub district in Figures year 2011. BPS Kecamatan Haharu.

Badan Pusat Statistik (BPS). 2012. Haharu sub district in Figures year 2012. BPS Kecamatan Haharu.

Badan Pusat Statistik (BPS). 2013. Haharu sub district in Figures year 2013. BPS Kecamatan Haharu.

Badan Pusat Statistik (BPS). 2014. Haharu sub district in Figures year 2014. BPS Kecamatan Haharu.

Badan Pusat Statistik (BPS). 2015. East Sumba district in Figures year 2015. BPS Kecamatan Haharu.

de Foresta, H., Kusworo A, Michon G, Djatmiko WA. 2000. KetikaKebunBerupaHutan Agroforest Khas Indonesia. World Agroforestry Centre (ICRAF). Bogor.

Hutabarat, S. 2006. Model Forest: Alternatif Pengelolaan Hutan di Nusa Tenggara Timur. Prosiding Sosialisasi Hasil-Hasil Penelitian Kehutanan. Pusat Litbang Hutan dan Konservasi Alam. Bogor.

Martini E, Saad U, Angreiny Y, Roshetko JM. 2014. KebunBelajarAgroforestri: KonsepdanPembelajarandari Sulawesi Selatan dan Tenggara. Paper presented at Seminar Nasional Agroforestri ke-5, 21 Nov 2014, Ambon, Indonesia.

Martini E, Saad U, Angreiny Y, Roshetko JM, Gunawan H, Maulana HT, Suganda G, Dwipayana G, Erwin LO, Hadedi A. 2016. Agroforestry and Forestry in Sulawesi series: Evaluation of the Agroforestry Farmer Field Schools on agroforestry management in South and Southeast Sulawesi, Indonesia. Working paper 220. Bogor, Indonesia: World Agroforestry Centre (ICRAF) Southeast Asia Regional Program. 16p. DOI: 10.5716/WP16002.PDF.

Monk, K.A., Y. de Fretes and G. Reksodiharjo-Lilley. 1997. The ecology of Nusa Tenggara and Maluku. The ecology of Indonesia series, volume 5. Dalhousie University, Nova Scotia, Canada.

Njurumana GND. 2008. RehabilitasiLahanKritisBerbasisAgrosylvopastur di Timor dan Sumba, Nusa Tenggara Timur. Info Hutan Vol V(2): 99-112.

Njurumana, GND, Prasetyo, BD. 2010. Lende Ura, Sebuah Inisiatif Masyarakat dalam Rehabilitasi Hutan dan Lahan di Sumba Barat Daya. Jurnal Analisis Kebijakan kehutanan Vol 7(2): 97-110.

Radandima, U. 2001. Pengembangan masyarakat dalam pengelolaan sumber daya alam melalui program wanatani. Pengalaman Yayasan Tananua Sumba. In: JM Roshetko, Mulawarman, WJ Santoso and I.N. Oka. Wanatani di Nusa Tenggara. Prosiding Lokakarya Wanatani Se-Nusa Tenggara (Agroforestry in Nusa Tenggara, Proceedings of a Workshop), 11-14 November 2001. Denpasar, Bali. International Centre for Research in Agroforestry (ICRAF) and Winrock International

Rinaudo, T. 2012. Natural Resources Advisor, World Vision Australia and pioneer of Farmer Managed Natural Regeneration in Niger in 1983. World Vision Australia.

Roshetko JM and Mulawarman. 2002. Wanatani di Nusa Tenggara: Ringkasanhasillokakarya (Agroforestry for Nusa Tenggara: A Summary of Workshop Outputs). In: JM Roshetko, Mulawarman, WJ Santoso and I.N. Oka. Wanatani di Nusa Tenggara. Prosiding Lokakarya 
Wanatani Se-Nusa Tenggara (Agroforestry in Nusa Tenggara, Proceedings of a Workshop), 11-14 November 2001. Denpasar, Bali. International Centre for Research in Agroforestry (ICRAF) and Winrock International.

Stubenvoll, S. 2000. Traditional Agroforestry and Ecological, Social, and Economic Sustaqinability on Small Tropical Islands: A dynamic land-use system and its potential for community-basd development in Tioor and Rhun, Central Maluku, Indonesia. Doctoral Dissertation. School of Architecture - Environment - Society, Technical University of Berlin. 


\section{Annex 1. Sketchs of Wunga, Kadahang and Rambangaru villages}

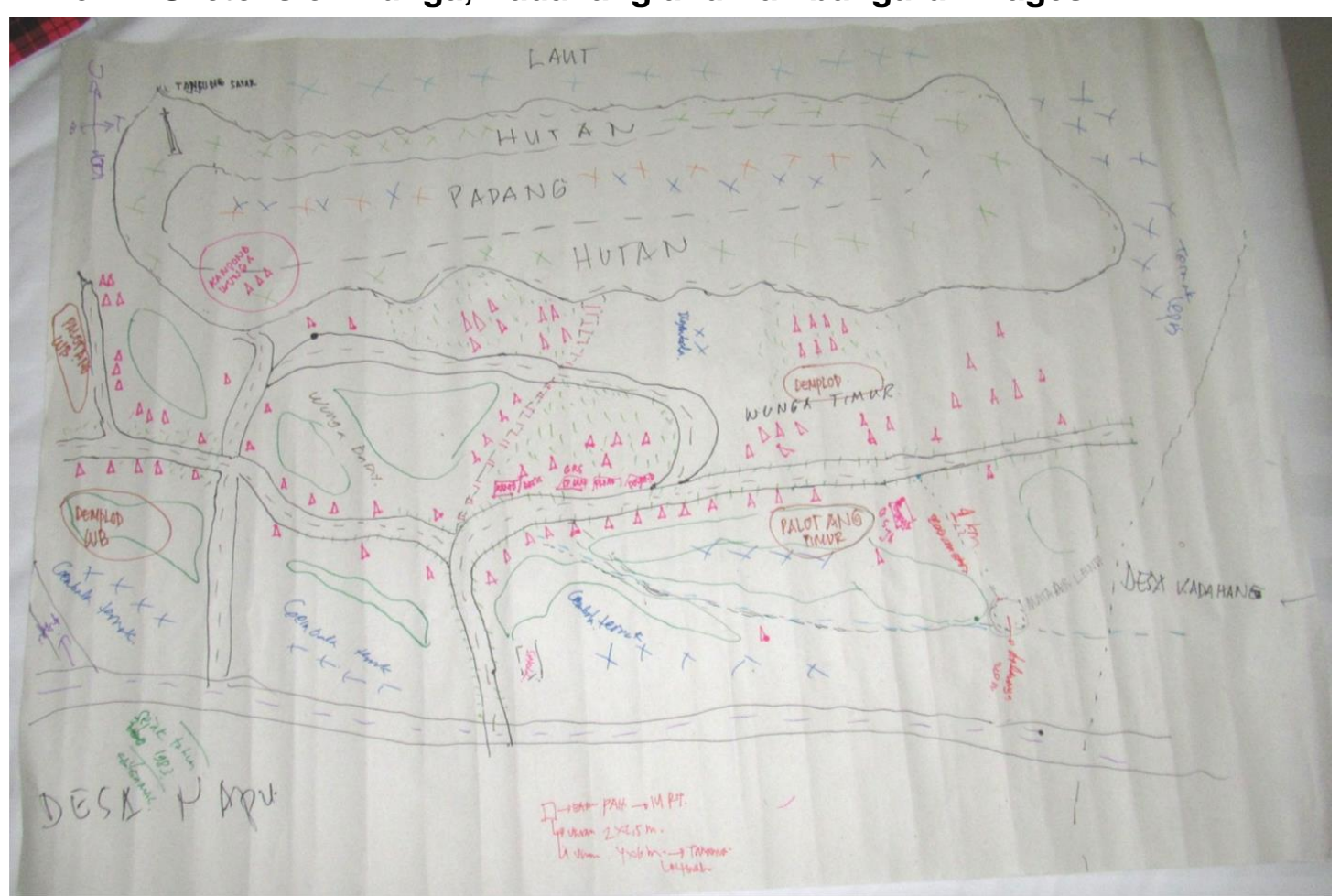

Figure 6. Wunga village, Haharu subdistrict, East Sumba

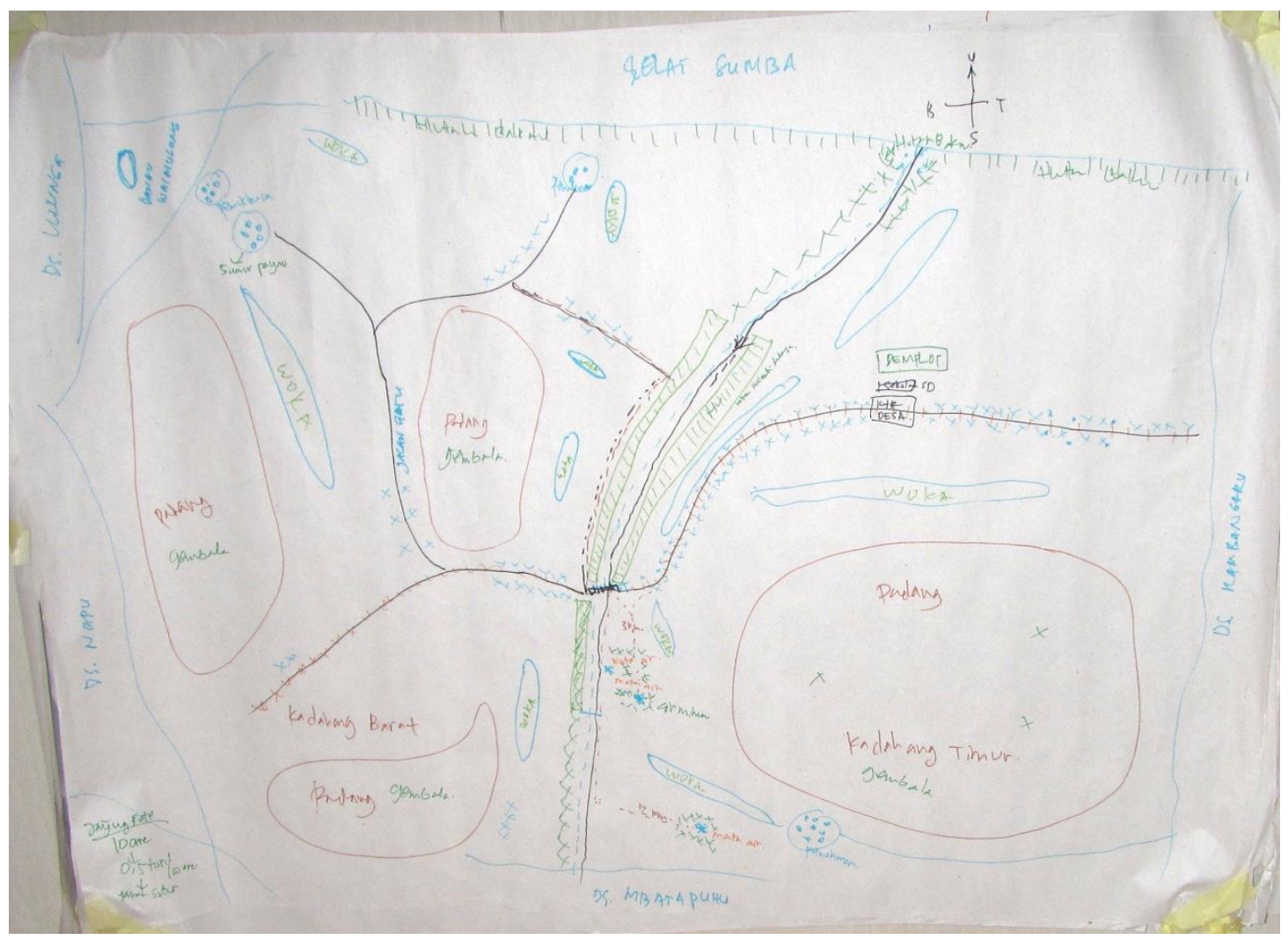

Figure 7. Kadahang village, Haharu subdistrict, East Sumba 


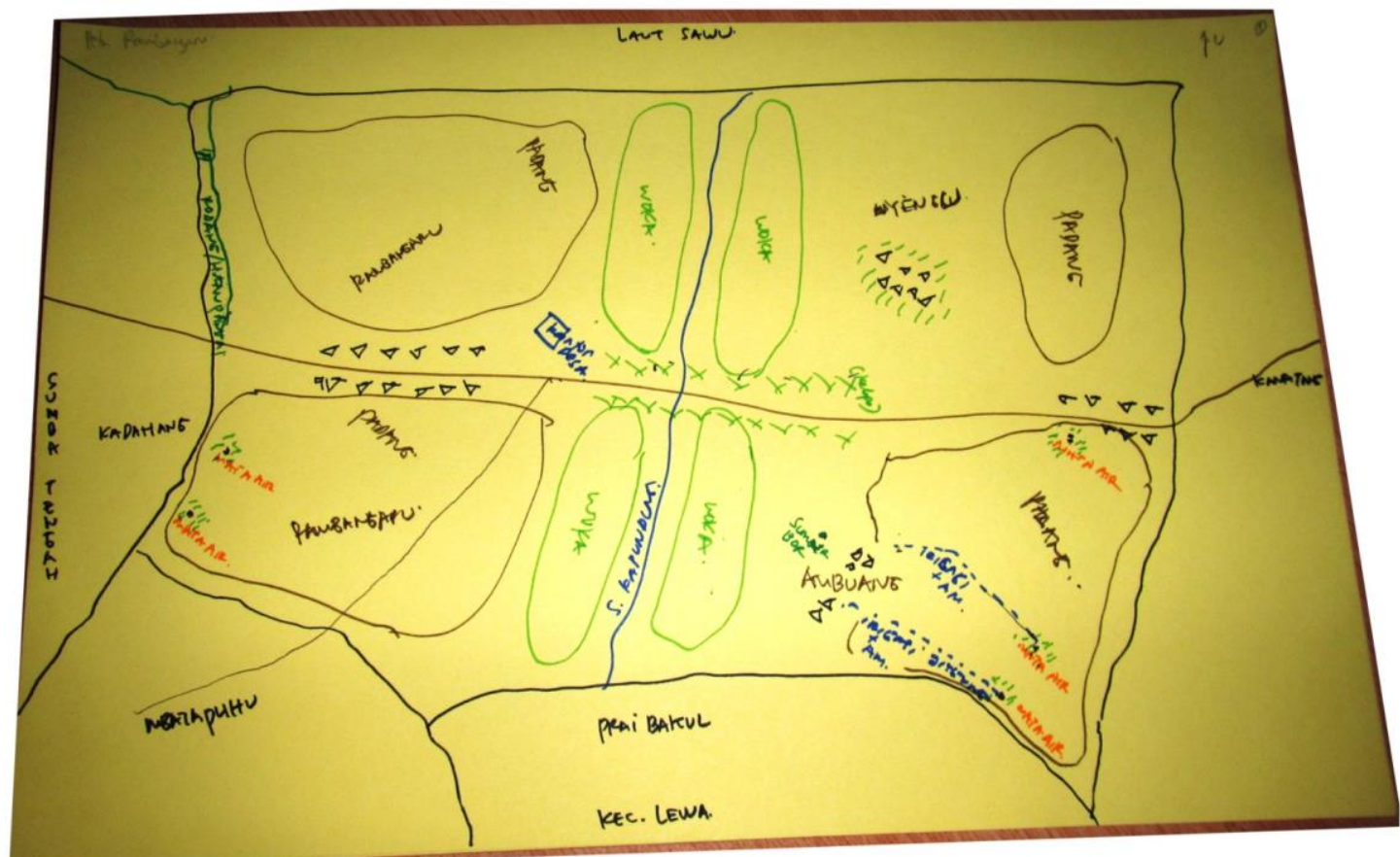

Figure 8. Rambangaru village, Haharu subdistrict, East Sumba 



\section{WORKING PAPERS WITH DOIS}

\section{5}

1. Agroforestry in the drylands of eastern Africa: a call to action

2. Biodiversity conservation through agroforestry: managing tree species diversity within a network of community-based, nongovernmental, governmental and research organizations in western Kenya.

3. Invasion of prosopis juliflora and local livelihoods: Case study from the Lake Baringo area of Kenya

4. Leadership for change in farmers organizations: Training report: Ridar Hotel, Kampala, 29th March to 2nd April 2005.

5. Domestication des espèces agroforestières au Sahel : situation actuelle et perspectives

6. Relevé des données de biodiversité ligneuse: Manuel du projet biodiversité des parcs agroforestiers au Sahel

7. Improved land management in the Lake Victoria Basin: TransVic Project's draft report.

8. Livelihood capital, strategies and outcomes in the Taita hills of Kenya

9. Les espèces ligneuses et leurs usages: Les préférences des paysans dans le Cercle de Ségou, au Mali

10. La biodiversité des espèces ligneuses: Diversité arborée et unités de gestion du terroir dans le Cercle de Ségou, au Mali

\section{6}

11. Bird diversity and land use on the slopes of Mt. Kilimanjaro and the adjacent plains, Tanzania

12. Water, women and local social organization in the Western Kenya Highlands

13. Highlights of ongoing research of the World Agroforestry Centre in Indonesia

14. Prospects of adoption of tree-based systems in a rural landscape and its likely impacts on carbon stocks and farmers' welfare: The FALLOW Model Application in Muara Sungkai, Lampung, Sumatra, in a 'Clean Development Mechanism' context

15. Equipping integrated natural resource managers for healthy Agroforestry landscapes.

17. Agro-biodiversity and CGIAR tree and forest science: approaches and examples from Sumatra.

18. Improving land management in eastern and southern Africa: A review of policies.

19. Farm and household economic study of Kecamatan Nanggung, Kabupaten Bogor, Indonesia: A socioeconomic base line study of Agroforestry innovations and livelihood enhancement.

20. Lessons from eastern Africa's unsustainable charcoal business.

21. Evolution of RELMA's approaches to land management: Lessons from two decades of research and development in eastern and southern Africa

22. Participatory watershed management: Lessons from RELMA's work with farmers in eastern Africa.

23. Strengthening farmers' organizations: The experience of RELMA and ULAMP.

24. Promoting rainwater harvesting in eastern and southern Africa.

25. The role of livestock in integrated land management.

26. Status of carbon sequestration projects in Africa: Potential benefits and challenges to scaling up.

27. Social and Environmental Trade-Offs in Tree Species Selection: A Methodology for Identifying Niche Incompatibilities in Agroforestry [Appears as AHI Working Paper no. 9]

28. Managing tradeoffs in agroforestry: From conflict to collaboration in natural resource management. [Appears as AHI Working Paper no. 10]

29. Essai d'analyse de la prise en compte des systemes agroforestiers pa les legislations forestieres au Sahel: Cas du Burkina Faso, du Mali, du Niger et du Senegal.

30. Etat de la recherche agroforestière au Rwanda etude bibliographique, période 1987-2003 
31. Science and technological innovations for improving soil fertility and management in Africa: A report for NEPAD's Science and Technology Forum.

32. Compensation and rewards for environmental services.

33. Latin American regional workshop report compensation.

34. Asia regional workshop on compensation ecosystem services.

35. Report of African regional workshop on compensation ecosystem services.

36. Exploring the inter-linkages among and between compensation and rewards for ecosystem services CRES and human well-being

37. Criteria and indicators for environmental service compensation and reward mechanisms: realistic, voluntary, conditional and pro-poor

38. The conditions for effective mechanisms of compensation and rewards for environmental services.

39. Organization and governance for fostering Pro-Poor Compensation for Environmental Services.

40. How important are different types of compensation and reward mechanisms shaping poverty and ecosystem services across Africa, Asia \& Latin America over the Next two decades?

41. Risk mitigation in contract farming: The case of poultry, cotton, woodfuel and cereals in East Africa.

42. The RELMA savings and credit experiences: Sowing the seed of sustainability

43. Yatich J., Policy and institutional context for NRM in Kenya: Challenges and opportunities for Landcare.

44. Nina-Nina Adoung Nasional di So! Field test of rapid land tenure assessment (RATA) in the Batang Toru Watershed, North Sumatera.

45. Is Hutan Tanaman Rakyat a new paradigm in community based tree planting in Indonesia?

46. Socio-Economic aspects of brackish water aquaculture (Tambak) production in Nanggroe Aceh Darrusalam.

47. Farmer livelihoods in the humid forest and moist savannah zones of Cameroon.

48. Domestication, genre et vulnérabilité : Participation des femmes, des Jeunes et des catégories les plus pauvres à la domestication des arbres agroforestiers au Cameroun.

49. Land tenure and management in the districts around Mt Elgon: An assessment presented to the Mt Elgon ecosystem conservation programme.

50. The production and marketing of leaf meal from fodder shrubs in Tanga, Tanzania: A pro-poor enterprise for improving livestock productivity.

51. Buyers Perspective on Environmental Services (ES) and Commoditization as an approach to liberate ES markets in the Philippines.

52. Towards Towards community-driven conservation in southwest China: Reconciling state and local perceptions.

53. Biofuels in China: An Analysis of the Opportunities and Challenges of Jatropha curcas in Southwest China.

54. Jatropha curcas biodiesel production in Kenya: Economics and potential value chain development for smallholder farmers

55. Livelihoods and Forest Resources in Aceh and Nias for a Sustainable Forest Resource Management and Economic Progress

56. Agroforestry on the interface of Orangutan Conservation and Sustainable Livelihoods in Batang Toru, North Sumatra. 
57. Assessing Hydrological Situation of Kapuas Hulu Basin, Kapuas Hulu Regency, West Kalimantan.

58. Assessing the Hydrological Situation of Talau Watershed, Belu Regency, East Nusa Tenggara.

59. Kajian Kondisi Hidrologis DAS Talau, Kabupaten Belu, Nusa Tenggara Timur.

60. Kajian Kondisi Hidrologis DAS Kapuas Hulu, Kabupaten Kapuas Hulu, Kalimantan Barat.

61. Lessons learned from community capacity building activities to support agroforest as sustainable economic alternatives in Batang Toru orang utan habitat conservation program (Martini, Endri et al.)

62. Mainstreaming Climate Change in the Philippines.

63. A Conjoint Analysis of Farmer Preferences for Community Forestry Contracts in the Sumber Jaya Watershed, Indonesia.

64. The highlands: a shared water tower in a changing climate and changing Asia

65. Eco-Certification: Can It Deliver Conservation and Development in the Tropics.

66. Designing ecological and biodiversity sampling strategies. Towards mainstreaming climate change in grassland management.

67. Towards mainstreaming climate change in grassland management policies and practices on the Tibetan Plateau

68. An Assessment of the Potential for Carbon Finance in Rangelands

69 ECA Trade-offs Among Ecosystem Services in the Lake Victoria Basin.

69. The last remnants of mega biodiversity in West Java and Banten: an in-depth exploration of RaTA (Rapid Land Tenure Assessment) in Mount Halimun-Salak National Park Indonesia

70. Le business plan d'une petite entreprise rurale de production et de commercialisation des plants des arbres locaux. Cas de quatre pépinières rurales au Cameroun.

71. Les unités de transformation des produits forestiers non ligneux alimentaires au Cameroun. Diagnostic technique et stratégie de développement Honoré Tabuna et Ingratia Kayitavu.

72. Les exportateurs camerounais de safou (Dacryodes edulis) sur le marché sous régional et international. Profil, fonctionnement et stratégies de développement.

73. Impact of the Southeast Asian Network for Agroforestry Education (SEANAFE) on agroforestry education capacity.

74. Setting landscape conservation targets and promoting them through compatible land use in the Philippines.

75. Review of methods for researching multistrata systems.

76. Study on economical viability of Jatropha curcas L. plantations in Northern Tanzania assessing farmers' prospects via cost-benefit analysis

77. Cooperation in Agroforestry between Ministry of Forestry of Indonesia and International Center for Research in Agroforestry

78. "China's bioenergy future. an analysis through the Lens if Yunnan Province

79. Land tenure and agricultural productivity in Africa: A comparative analysis of the economics literature and recent policy strategies and reforms

80. Boundary organizations, objects and agents: linking knowledge with action in Agroforestry watersheds

81. Reducing emissions from deforestation and forest degradation (REDD) in Indonesia: options and challenges for fair and efficient payment distribution mechanisms 
82. Mainstreaming climate change into agricultural education: challenges and perspectives

83. Challenging conventional mindsets and disconnects in conservation: the emerging role of ecoagriculture in Kenya's landscape mosaics

84. Lesson learned RATA garut dan bengkunat: suatu upaya membedah kebijakan pelepasan kawasan hutan dan redistribusi tanah bekas kawasan hutan

85. The emergence of forest land redistribution in Indonesia

86. Commercial opportunities for fruit in Malawi

87. Status of fruit production processing and marketing in Malawi

88. Fraud in tree science

89. Trees on farm: analysis of global extent and geographical patterns of agroforestry

90. The springs of Nyando: water, social organization and livelihoods in Western Kenya

91. Building capacity toward region-wide curriculum and teaching materials development in agroforestry education in Southeast Asia

92. Overview of biomass energy technology in rural Yunnan (Chinese - English abstract)

93. A pro-growth pathway for reducing net GHG emissions in China

94. Analysis of local livelihoods from past to present in the central Kalimantan Ex-Mega Rice Project area

95. Constraints and options to enhancing production of high quality feeds in dairy production in Kenya, Uganda and Rwanda

2010

96. Agroforestry education in the Philippines: status report from the Southeast Asian Network for Agroforestry Education (SEANAFE)

97. Economic viability of Jatropha curcas L. plantations in Northern Tanzania- assessing farmers' prospects via cost-benefit analysis.

98. Hot spot of emission and confusion: land tenure insecurity, contested policies and competing claims in the central Kalimantan Ex-Mega Rice Project area

99. Agroforestry competences and human resources needs in the Philippines

100. CES/COS/CIS paradigms for compensation and rewards to enhance environmental Services

101. Case study approach to region-wide curriculum and teaching materials development in agroforestry education in Southeast Asia

102. Stewardship agreement to reduce emissions from deforestation and degradation (REDD): Lubuk Beringin's Hutan Desa as the first village forest in Indonesia

103. Landscape dynamics over time and space from ecological perspective

104. Komoditisasi atau koinvestasi jasa lingkungan: skema imbal jasa lingkungan program peduli sungai di DAS Way Besai, Lampung, Indonesia

105. Improving smallholders' rubber quality in Lubuk Beringin, Bungo district, Jambi province, Indonesia: an initial analysis of the financial and social benefits

106. Rapid Carbon Stock Appraisal (RACSA) in Kalahan, Nueva Vizcaya, Philippines

107. Tree domestication by ICRAF and partners in the Peruvian Amazon: lessons learned and future prospects in the domain of the Amazon Initiative eco-regional program

108. Memorias del Taller Nacional: "Iniciativas para Reducir la Deforestación en la region Andino Amazónica", 09 de Abril del 2010. Proyecto REALU Peru

109. Percepciones sobre la Equidad y Eficiencia en la cadena de valor de REDD en Perú -Reporte de Talleres en Ucayali, San Martín y Loreto, 2009. Proyecto REALU-Perú. 
110. Reducción de emisiones de todos los Usos del Suelo. Reporte del Proyecto REALU Perú Fase 1

111. Programa Alternativas a la Tumba-y-Quema (ASB) en el Perú. Informe Resumen y Síntesis de la Fase II. 2da. versión revisada

112. Estudio de las cadenas de abastecimiento de germoplasma forestal en la amazonía Boliviana

113. Biodiesel in the Amazon

114. Estudio de mercado de semillas forestales en la amazonía Colombiana

115. Estudio de las cadenas de abastecimiento de germoplasma forestal en Ecuador http://dx.doi.org10.5716/WP10340.PDF

116. How can systems thinking, social capital and social network analysis help programs achieve impact at scale?

117. Energy policies, forests and local communities in the Ucayali Region, Peruvian Amazon

118. NTFPs as a Source of Livelihood Diversification for Local Communities in the Batang Toru Orangutan Conservation Program

119. Studi Biodiversitas: Apakah agroforestry mampu mengkonservasi keanekaragaman hayati di DAS Konto?

120. Estimasi Karbon Tersimpan di Lahan-lahan Pertanian di DAS Konto, Jawa Timur

121. Implementasi Kaji Cepat Hidrologi (RHA) di Hulu DAS Brantas, Jawa Timur. http://dx.doi.org/10.5716/WP10338.PDF

122. Kaji Cepat Hidrologi di Daerah Aliran Sungai Krueng Peusangan, NAD,Sumatra http://dx.doi.org/10.5716/WP10337.PDF

123. A Study of Rapid Hydrological Appraisal in the Krueng Peusangan Watershed, NAD, Sumatra. http://dx.doi.org/10.5716/WP10339.PDF

2011

124. An Assessment of farm timber value chains in Mt Kenya area, Kenya

125. A Comparative financial analysis of current land use systems and implications for the adoption of improved agroforestry in the East Usambaras, Tanzania

126. Agricultural monitoring and evaluation systems

127. Challenges and opportunities for collaborative landscape governance in the East Usambara Mountains, Tanzania

128. Transforming Knowledge to Enhance Integrated Natural Resource Management Research, Development and Advocacy in the Highlands of Eastern Africa http://dx.doi.org/10.5716/WP11084.PDF

129. Carbon-forestry projects in the Philippines: potential and challenges The Mt Kitanglad Range forestcarbon development http://dx.doi.org10.5716/WP11054.PDF

130. Carbon forestry projects in the Philippines: potential and challenges. The Arakan Forest Corridor forest-carbon project. http://dx.doi.org10.5716/WP11055.PDF

131. Carbon-forestry projects in the Philippines: potential and challenges. The Laguna Lake Development Authority's forest-carbon development project. http://dx.doi.org/10.5716/WP11056.PDF

132. Carbon-forestry projects in the Philippines: potential and challenges. The Quirino forest-carbon development project in Sierra Madre Biodiversity Corridor http://dx.doi.org10.5716/WP11057.PDF

133. Carbon-forestry projects in the Philippines: potential and challenges. The Ikalahan Ancestral Domain forest-carbon development http://dx.doi.org10.5716/WP11058.PDF

134. The Importance of Local Traditional Institutions in the Management of Natural Resources in the Highlands of Eastern Africa. http://dx.doi.org/10.5716/WP11085.PDF 
135. Socio-economic assessment of irrigation pilot projects in Rwanda. http://dx.doi.org/10.5716/WP11086.PDF

136. Performance of three rambutan varieties (Nephelium lappaceum L.) on various nursery media. http://dx.doi.org/10.5716/WP11232.PDF

137. Climate change adaptation and social protection in agroforestry systems: enhancing adaptive capacity and minimizing risk of drought in Zambia and Honduras http://dx.doi.org/10.5716/WP11269.PDF

138. Does value chain development contribute to rural poverty reduction? Evidence of asset building by smallholder coffee producers in Nicaragua http://dx.doi.org/10.5716/WP11271.PDF

139. Potential for biofuel feedstock in Kenya. http://dx.doi.org/10.5716/WP11272.PDF

140. Impact of fertilizer trees on maize production and food security in six districts of Malawi. http://dx.doi.org/10.5716/WP11281.PDF

\section{2}

141. Fortalecimiento de capacidades para la gestión del Santuario Nacional Pampa Hermosa:

Construyendo las bases para un manejo adaptativo para el desarrollo local. Memorias del Proyecto. http://dx.doi.org/10.5716/WP12005.PDF

142. Understanding rural institutional strengthening: A cross-level policy and institutional framework for sustainable development in Kenya http://dx.doi.org/10.5716/WP12012.PDF

143. Climate change vulnerability of agroforestry http://dx.doi.org/10.5716/WP16722.PDF

144. Rapid assesment of the inner Niger delta of Mali http://dx.doi.org/10.5716/WP12021.PDF

145. Designing an incentive program to reduce on-farm deforestationin the East Usambara Mountains, Tanzania http://dx.doi.org/10.5716/WP12048.PDF

146. Extent of adoption of conservation agriculture and agroforestry in Africa: the case of Tanzania, Kenya, Ghana, and Zambia http://dx.doi.org/10.5716/WP12049.PDF

147. Policy incentives for scaling up conservation agriculture with trees in Africa: the case of Tanzania, Kenya, Ghana and Zambia http://dx.doi.org/10.5716/WP12050.PDF

148. Commoditized or co-invested environmental services? Rewards for environmental services scheme: River Care program Way Besai watershed, Lampung, Indonesia. http://dx.doi.org/10.5716/WP12051.PDF

149. Assessment of the headwaters of the Blue Nile in Ethiopia. http://dx.doi.org/10.5716/WP12160.PDF

150. Assessment of the uThukela Watershed, Kwazaulu. http://dx.doi.org/10.5716/WP12161.PDF

151. Assessment of the Oum Zessar Watershed of Tunisia. http://dx.doi.org/10.5716/WP12162.PDF

152. Assessment of the Ruwenzori Mountains in Uganda. http://dx.doi.org/10.5716/WP12163.PDF

153. History of agroforestry research and development in Viet Nam. Analysis of research opportunities and gaps. http://dx.doi.org/10.5716/WP12052.PDF

154. REDD+ in Indonesia: a Historical Perspective. http://dx.doi.org/10.5716/WP12053.PDF

155. Agroforestry and Forestry in Sulawesi series: Livelihood strategies and land use system dynamics in South Sulawesi http://dx.doi.org/10.5716/WP12054.PDF

156. Agroforestry and Forestry in Sulawesi series: Livelihood strategies and land use system dynamics in Southeast Sulawesi. http://dx.doi.org/10.5716/WP12055.PDF

157. Agroforestry and Forestry in Sulawesi series: Profitability and land-use systems in South and Southeast Sulawesi. http://dx.doi.org/10.5716/WP12056.PDF

158. Agroforestry and Forestry in Sulawesi series: Gender, livelihoods and land in South and Southeast Sulawesi http://dx.doi.org/10.5716/WP12057.PDF 
159. Agroforestry and Forestry in Sulawesi series: Agroforestry extension needs at the community level in AgFor project sites in South and Southeast Sulawesi, Indonesia. http://dx.doi.org/10.5716/WP12058.PDF

160. Agroforestry and Forestry in Sulawesi series: Rapid market appraisal of agricultural, plantation and forestry commodities in South and Southeast Sulawesi. http://dx.doi.org/10.5716/WP12059.PDF

\section{3}

161. Diagnosis of farming systems in the Agroforestry for Livelihoods of Smallholder farmers in Northwestern Viet Nam project http://dx.doi.org/10.5716/WP13033.PDF

162. Ecosystem vulnerability to climate change: a literature review. http://dx.doi.org/10.5716/WP13034.PDF

163. Local capacity for implementing payments for environmental services schemes: lessons from the RUPES project in northeastern Viet Nam http://dx.doi.org/10.5716/WP13046.PDF

164. Seri Agroforestri dan Kehutanan di Sulawesi: Agroforestry dan Kehutanan di Sulawesi: Strategi mata pencaharian dan dinamika sistem penggunaan lahan di Sulawesi Selatan http://dx.doi.org/10.5716/WP13040.PDF

165. Seri Agroforestri dan Kehutanan di Sulawesi: Mata pencaharian dan dinamika sistem penggunaan lahan di Sulawesi Tenggara http://dx.doi.org/10.5716/WP13041.PDF

166. Seri Agroforestri dan Kehutanan di Sulawesi: Profitabilitas sistem penggunaan lahan di Sulawesi Selatan dan Sulawesi Tenggara http://dx.doi.org/10.5716/WP13042.PDF

167. Seri Agroforestri dan Kehutanan di Sulawesi: Gender, mata pencarian dan lahan di Sulawesi Selatan dan Sulawesi Tenggara http://dx.doi.org/10.5716/WP13043.PDF

168. Seri Agroforestri dan Kehutanan di Sulawesi: Kebutuhan penyuluhan agroforestri pada tingkat masyarakat di lokasi proyek AgFor di Sulawesi Selatan dan Tenggara, Indonesia. http://dx.doi.org/10.5716/WP13044.PDF

169. Seri Agroforestri dan Kehutanan di Sulawesi: Laporan hasil penilaian cepat untuk komoditas pertanian, perkebunan dan kehutanan di Sulawesi Selatan dan Tenggara http://dx.doi.org/10.5716/WP13045.PDF

170. Agroforestry, food and nutritional security http://dx.doi.org/10.5716/WP13054.PDF

171. Stakeholder Preferences over Rewards for Ecosystem Services: Implications for a REDD+ Benefit Distribution System in Viet Nam http://dx.doi.org/10.5716/WP13057.PDF

172. Payments for ecosystem services schemes: project-level insights on benefits for ecosystems and the rural poor http://dx.doi.org/10.5716/WP13001.PDF

173. Good practices for smallholder teak plantations: keys to success http://dx.doi.org/10.5716/WP13246.PDF

174. Market analysis of selected agroforestry products in the Vision for Change Project intervention Zone, Côte d'Ivoire http://dx.doi.org/10.5716/WP13249.PDF

175. Rattan futures in Katingan: why do smallholders abandon or keep their gardens in Indonesia's 'rattan district'? http://dx.doi.org/10.5716/WP13251.PDF

176. Management along a gradient: the case of Southeast Sulawesi's cacao production landscapes http://dx.doi.org/10.5716/WP13265.PDF 
177. Are trees buffering ecosystems and livelihoods in agricultural landscapes of the Lower Mekong Basin? Consequences for climate-change adaptation. http://dx.doi.org/10.5716/WP14047.PDF

178. Agroforestry, livestock, fodder production and climate change adaptation and mitigation in East Africa: issues and options. http://dx.doi.org/10.5716/WP14050.PDF

179. Trees on farms: an update and reanalysis of agroforestry's global extent and socio-ecological characteristics. http://dx.doi.org/10.5716/WP14064.PDF

180. Beyond reforestation: an assessment of Vietnam's REDD+ readiness. http://dx.doi.org/10.5716/WP14097.PDF

181. Farmer-to-farmer extension in Kenya: the perspectives of organizations using the approach. http://dx.doi.org/10.5716/WP14380.PDF

182. Farmer-to-farmer extension in Cameroon: a survey of extension organizations. http://dx.doi.org/10.5716/WP14383.PDF

183. Farmer-to-farmer extension approach in Malawi: a survey of organizations: a survey of organizations http://dx.doi.org/10.5716/WP14391.PDF

184. Seri Agroforestri dan Kehutanan di Sulawesi: Kuantifikasi jasa lingkungan air dan karbon pola agroforestri pada hutan rakyat di wilayah sungai Jeneberang

185. Options for Climate-Smart Agriculture at Kaptumo Site in Kenyahttp://dx.doi.org/10.5716/WP14394.PDF

\section{5}

186. Agroforestry for Landscape Restoration and Livelihood Development in Central Asia http://dx.doi.org/10.5716/WP14143.PDF

187. "Projected Climate Change and Impact on Bioclimatic Conditions in the Central and South-Central Asia Region" http://dx.doi.org/10.5716/WP14144.PDF

188. Land Cover Changes, Forest Loss and Degradation in Kutai Barat, Indonesia. http://dx.doi.org/10.5716/WP14145.PDF

189. The Farmer-to-Farmer Extension Approach in Malawi: A Survey of Lead Farmers. http://dx.doi.org/10.5716/WP14152.PDF

190. Evaluating indicators of land degradation and targeting agroforestry interventions in smallholder farming systems in Ethiopia. http://dx.doi.org/10.5716/WP14252.PDF

191. Land health surveillance for identifying land constraints and targeting land management options in smallholder farming systems in Western Cameroon

192. Land health surveillance in four agroecologies in Malawi

193. Cocoa Land Health Surveillance: an evidence-based approach to sustainable management of cocoa landscapes in the Nawa region, South-West Côte d'Ivoire http://dx.doi.org/10.5716/WP14255.PDF

194. Situational analysis report: Xishuangbanna autonomous Dai Prefecture, Yunnan Province, China. http://dx.doi.org/10.5716/WP14255.PDF

195. Farmer-to-farmer extension: a survey of lead farmers in Cameroon. http://dx.doi.org/10.5716/WP15009.PDF

196. From transition fuel to viable energy source Improving sustainability in the sub-Saharan charcoal sector http://dx.doi.org/10.5716/WP15011.PDF

197. Mobilizing Hybrid Knowledge for More Effective Water Governance in the Asian Highlands http://dx.doi.org/10.5716/WP15012.PDF

198. Water Governance in the Asian Highlands http://dx.doi.org/10.5716/WP15013.PDF

199. Assessing the Effectiveness of the Volunteer Farmer Trainer Approach in Dissemination of Livestock Feed Technologies in Kenya vis-à-vis other Information Sources

http://dx.doi.org/10.5716/WP15022.PDF 
200. The rooted pedon in a dynamic multifunctional landscape: Soil science at the World Agroforestry Centre http://dx.doi.org/10.5716/WP15023.PDF

201. Characterising agro-ecological zones with local knowledge. Case study: Huong Khe district, Ha Tinh, Viet Nam http://dx.doi.org/10.5716/WP15050.PDF

202. Looking back to look ahead: Insight into the effectiveness and efficiency of selected advisory approaches in the dissemination of agricultural technologies indicative of Conservation Agriculture with Trees in Machakos County, Kenya. http://dx.doi.org/10.5716/WP15065.PDF

203. Pro-poor Biocarbon Projects in Eastern Africa Economic and Institutional Lessons. http://dx.doi.org/10.5716/WP15022.PDF

204. Projected climate change impacts on climatic suitability and geographical distribution of banana and coffee plantations in Nepal. http://dx.doi.org/10.5716/WP15294.PDF

205. Agroforestry and Forestry in Sulawesi series: Smallholders' coffee production and marketing in Indonesia. A case study of two villages in South Sulawesi Province. http://dx.doi.org/10.5716/WP15690.PDF

206. Mobile phone ownership and use of short message service by farmer trainers: a case study of Olkalou and Kaptumo in Kenya http://dx.doi.org/10.5716/WP15691.PDF

207. Associating multivariate climatic descriptors with cereal yields: a case study of Southern Burkina Faso http://dx.doi.org/10.5716/WP15273.PDF

208. Preferences and adoption of livestock feed practices among farmers in dairy management groups in Kenya http://dx.doi.org/10.5716/WP15675.PDF

209. Scaling up climate-smart agriculture: lessons learned from South Asia and pathways for success http://dx.doi.org/10.5716/WP15720.PDF

210. Agroforestry and Forestry in Sulawesi series: Local perceptions of forest ecosystem services and collaborative formulation of reward mechanisms in South and Southeast Sulawesi http://dx.doi.org/10.5716/WP15721.PDF

211. Potential and challenges in implementing the co-investment of ecosystem services scheme in Buol District, Indonesia. http://dx.doi.org/10.5716/WP15722.PDF

212. Tree diversity and its utilization by the local community in Buol District, Indonesia http://dx.doi.org/10.5716/WP15723.PDF

213 Vulnerability of smallholder farmers and their preferences on farming practices in Buol District, Indonesia http://dx.doi.org/10.5716/WP15724.PDF

214. Dynamics of Land Use/Cover Change and Carbon Emission in Buol District, Indonesia http://dx.doi.org/10.5716/WP15725.PDF

215. Gender perspective in smallholder farming practices in Lantapan, Phillippines. http://dx.doi.org/10.5716/WP15726.PDF

216. Vulnerability of smallholder farmers in Lantapan, Bukidnon. http://dx.doi.org/10.5716/WP15727.PDF

217. Vulnerability and adaptive capacity of smallholders in Ho Ho sub-watershed, north-central Viet Nam http://dx.doi.org/10.5716/WP15728.PDF

218. Local knowledge on the role of trees to enhance livelihoods and ecosystem services in Ho Ho Subwatershed, north-central Viet Nam http://dx.doi.org/10.5716/WP15729.PDF

219. Landuse/cover change in Ho Ho Sub-watershed, north-central Viet Nam. http://dx.doi.org/10.5716/WP15730.PDF 
220. Agroforestry and Forestry in Sulawesi series: Evaluation of the Agroforestry Farmer Field Schools on agroforestry management in South and Southeast Sulawesi, Indonesia.

http://dx.doi.org/10.5716/WP16002.PDF

221 Farmer-to-farmer extension of livestock feed technologies in Rwanda: A survey of volunteer farmer trainers and organizations. http://dx.doi.org/10.5716/WP16005.PDF

222 Projected Climate Change Impact on Hydrology, Bioclimatic Conditions, and Terrestrial Ecosystems in the Asian Highlands http://dx.doi.org/10.5716/WP16006.PDF

223 Adoption of Agroforestry and its impact on household food security among farmers in Malawi http://dx.doi.org/10.5716/WP16013.PDF

224 Agroforestry and Forestry in Sulawesi series: Information channels for disseminating innovative agroforestry practices to villages in Southern Sulawesi, Indonesia http://dx.doi.org/10.5716/WP16034.PDF

225 Agroforestry and Forestry in Sulawesi series: Unravelling rural migration networks.Land-tenure arrangements among Bugis migrant communities in Southeast Sulawesi. http://dx.doi.org/10.5716/WP16035.PDF

226 Agroforestry and Forestry in Sulawesi series: Women's participation in agroforestry: more benefit or burden? A gendered analysis of Gorontalo Province. http://dx.doi.org/10.5716/WP16036.PDF

227 Kajian Kelayakan dan Pengembangan Desain Teknis Rehabilitasi Pesisir di Sulawesi Tengah. http://dx.doi.org/10.5716/WP16037.PDF

228. Selection of son tra clones in North West Vietnam. http://dx.doi.org/10.5716/WP16038.PDF

229. Growth and fruit yield of seedlings, cuttings and grafts from selected son tra trees in Northwest Vietnam http://dx.doi.org/10.5716/WP16046.PDF

230. Gender-Focused Analysis of Poverty and Vulnerability in Yunnan, China. http://dx.doi.org/10.5716/WP16071.PDF

231. Kebutuhan Penyuluhan Agroforestri untuk Rehabilitasi Lahan di Sumba Timur, Nusa Tenggara Timur, Indonesia.http://dx.doi.org/10.5716/WP16077.PDF

232. Agroforestry extension needs for land rehabilitation in East Sumba, East Nusa Tenggara, Indonesia http://dx.doi.org/10.5716/WP16078.PDF 

The World Agroforestry Centre is an autonomous, non-profit research organization whose vision is a rural transformation in the developing world as smallholder households increase their use of trees in agricultural landscapes to improve food security, nutrition, income, health, shelter, social cohesion, energy resources and environmental sustainability. The Centre generates science-based knowledge about the diverse roles that trees play in agricultural landscapes, and uses its research to advance policies and practices, and their implementation that benefit the poor and the environment. It aims to ensure that all this is achieved by enhancing the quality of its science work, increasing operational efficiency, building and maintaining strong partnerships, accelerating the use and impact of its research, and promoting greater cohesion, interdependence and alignment within the organization.

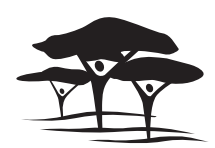

United Nations Avenue, Gigiri • PO Box 30677 • Nairobi, $00100 \cdot$ Kenya Telephone: +254 207224000 or via USA +1 6508336645 Fax: +254207224001 or via USA +16508336646 Email: worldagroforestry@cgiar.org•www.worldagroforestry.org

Southeast Asia Regional Program • Sindang Barang • Bogor 16680 PO Box $161 \cdot$ Bogor $16001 \cdot$ Indonesia

Telephone: +62 2518625415 • Fax: +62 2518625416 